\title{
ビブリオ属菌のべん毛関連遺伝子と機能
}

\author{
錦 野 達 郎 ${ }^{1}$ 小 小嶋 誠 司 $^{2} \cdot$ 本 間 道 夫 $^{2}$ \\ 1 大阪大学蛋白質研究所 \\ 2 名古屋大学大学院理学研究科生命理学専攻 \\ ${ }^{2}$ 个 464-8602 名古屋市千種区不老町 \\ E-mail: g44416a@cc.nagoya-u.ac.jp \\ [受理 : 2020 年 10 月]
}

\begin{abstract}
細菌はべん毛によって運動することができる。しかし, その運動は, 生育に全く必要ない。研究室の培養環境では, べん毛欠損株は, 野生株と全く同様に生育する。べん毛は 20 個以上の構成タンパク質から組み立てられ, それら のべん毛構造蛋白質をコードする遺伝子や発現を調節する遺伝子が 50 個以上存在する。べん毛の組み立てコスト は非常に大きなものであるが，運動器官として進化したということは，それだけ大きなコストをかけても，細菌 の生き残りには必要ということなのだ。本総説では, 筆者らが行ってきたべん毛関連研究とビブリオ属菌のべん 毛研究を中心に解説したい。
\end{abstract}

はじめに

ビブリオ属菌は, 海洋環境から広く分離され，増殖に一 般的にナトリウムを要求するグラム陰性通性嫌気性の細菌 である。多くのビブリオ細菌は桿菌であるが，やや曲がった バナナ状またはコンマ状の形態を示すものも存在する。コレ ラ菌Vibrio cholerae は, 下痢原性の細菌として約 150 年前に 発見されている (170)。腸炎ビブリオ菌V.parahaemolyticus もヒトに下痢を起こす病原菌として，1950 年に日本で分 離された (141)。海洋性ビブリオ菌V. alginolyticus はV. parahaemolyticus と非常に近縁ではあるが，ヒトに対して の病原性は萎とんどなく，一方で魚やエビなどには病原 性を持ち, 海中でキチン質などの分解に関与する海洋物質 分解サイクルに重要な菌である $(8,60)$ 。V vulnificus は普 段七トに病原性を示さないが, 免疫機能の低い人に侵入 すると全身感染を引き起こして人を死に至らしめる。 $V$ anguillarum は魚に感染して病気を引き起こす。V. fischeri も魚に感染性であるがこちらは, 発光バクテリアとして有 名である (10)。どの菌も菌体の極に一本から数本の極べん 毛 (Polar flagellum: Pof) をもつ。Harveyi クレードに属す るV.alginolyticus とV.parahaemolyticus は, 極べん毛に加光, 環境条件により極べん毛とは形態的に異なった側べん毛 (Lateral flagella: Laf) が, 菌体周囲に何十本も発現してく ることが知られている (104)。側べん毛は魚の表面への付 着や表面での移動に関与していることがわかっている。

\section{1. ビブリオ菌の分類と進化}

初期の細菌分類の指標では，桿菌であり活発に運動する 好塩性菌が，ビブリオ属として分類された。しかし， 16SRNA の配列やDNA 相同性試験によって，また最近で はゲノムの配列決定によって，その分類が大きく変更され ている $(148,170)$ 。ビブリオ属菌は，真性細菌のプロテ オバクテリア門・ガンマープロテオバクテリア綱の約 20

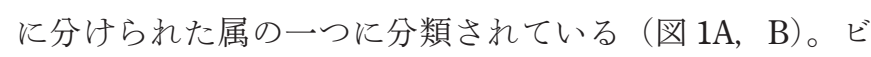
ブリオ科 (Vibrionaceae) の菌は，8つの属に分けられ， ビブリオ属菌は 14 のクレードに現在は分類されている(図 $1 C) 。$ 多くの細菌は 1 本の染色体を持っているが, ビブリ 才属の菌は, 大染色体 $(3 \sim 4 \mathrm{Mb})$ と小染色体 $(1 \sim 2 \mathrm{Mb})$ の 2 本の染色体を持っている $(27,128)$ 。従って, 総ゲ, ムサイズとしては，4〜 $6 \mathrm{Mb}$ となる。 $\gamma$ プロテオバクテリ アの中では, 他にPseudoalteromonas 属の染色体が 2 本で あることが分かっている。大染色体 (Chr1) は，E. coliの oriC に似た複製起点（ori1）をもち，複製開始因子である DnaA の結合ボックスが ori1 に存在している (29)。小染色 体（Chr2）の複製は，ビブリオ属に特有な複製開始因子 である RctB が ori2 に結合して，プラスミドの複製開始因 子に類似した機構で制御されていることが示されている (52,133)。Chr1 とChr2 が協調的に複製される必要があり, Chr1 の複製が阻害されるとChr2 の複製も阻害される機構 が備えられている $(137,138) 。 \gamma$ プロテオバクテリアに属 


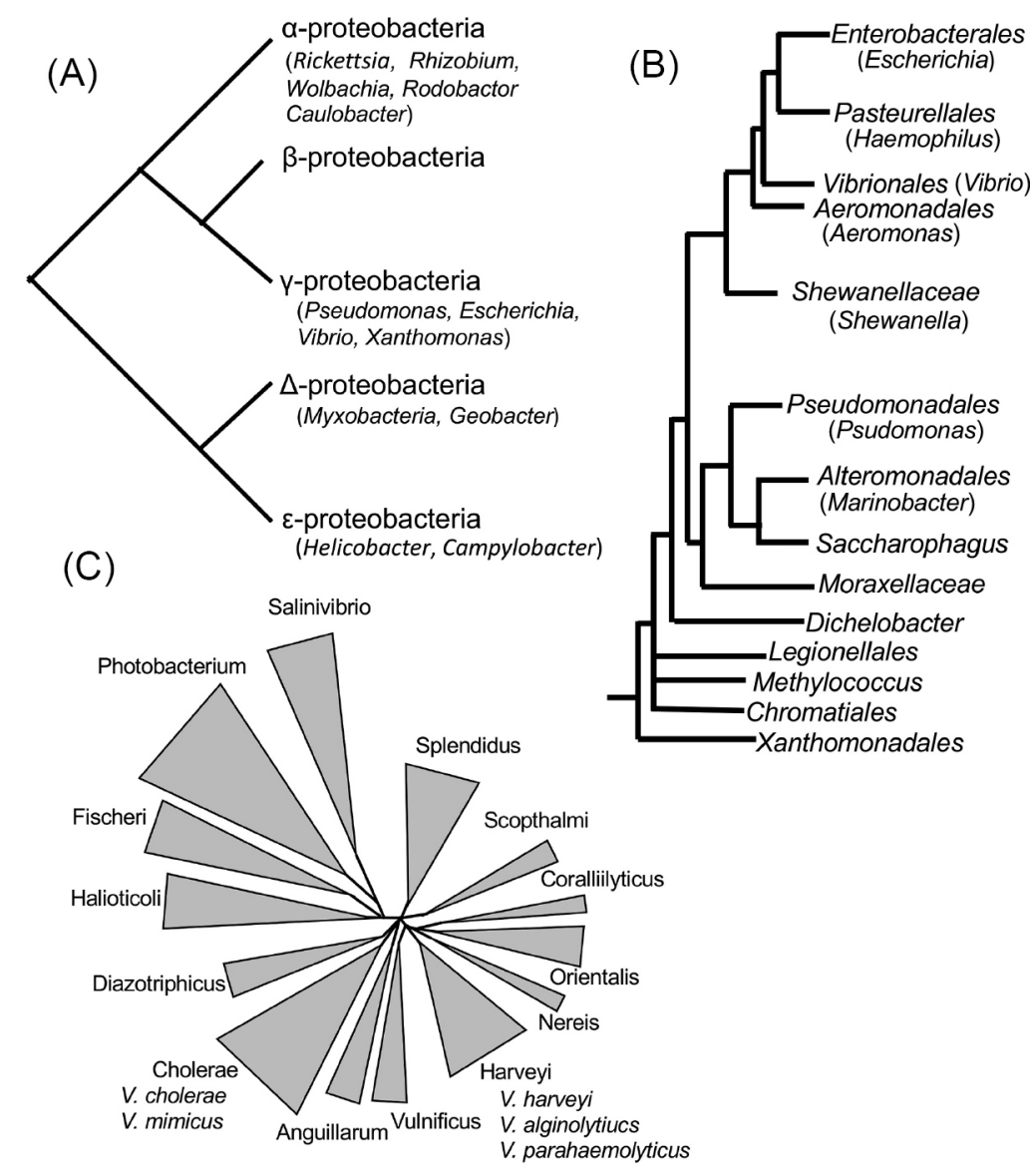

図1. 細菌の分類とビブリオ属菌の系統

(A) プロテオバクテリア門に属する主な細菌綱の系統。(B) ガンマープロテオバクテリア綱に属する細菌目の系統。(C) ビブリオ属 に属するビブリオ科細菌のクレード解析。澤辺らの論文（148）を参考に書いた。

する大腸菌 (Escherichia coli), シュワネラ菌 (Shewanella putrefaciens), 緑膿菌 (Pseudomonas aeruginosa) などは約 5〜6 Mb のゲノムサイズを持ち，1 本の染色体であること から，ビブリオ属菌の染色体は，プラスミド由来の複製開 始点が入り込み， 2 つレプリコンに分断されたと考えて もいいのかも知れない。2 本に分かれた利点として, 染色 体の複製が短時間で行光るといら推測がなされている (180)。ビブリオ属菌が早い増殖速度をもっていることと 関連が想像されている。

ビブリオ属菌のゲノム解析は, ヒトに病原性があるとい らことから，V. cholerae とV. parahaemolyticus の 2 種の菌が 進んでいる。V.cholerae とV.parahaemolyticus の 2 本の染色 体を比べてみると，V. cholerae が $2961 \mathrm{~kb}$ と $1072 \mathrm{~kb}$ に対し てV. parahaemolyticus は $3289 \mathrm{~kb}$ と $1877 \mathrm{~kb}$ であり，2 本の 染色体ともにV. cholerae の方が小さい $(39,87)$ （図 2)。V. parahaemolyticus の属する Harveyi クレードのV. harveryi の 染色体は， $3718 \mathrm{~kb}$ と $2321 \mathrm{~kb}$ と大きい(172)。染色体が 大きくなる原因としては，生存環境に応じて，より生き残 りに有利な遺伝子を取り込んだ結果であると推測できる。 この染色体の変化には, トランスポゾン ( Tn $)$ や挿入配列 (IS), ファージなどが染色体に入り込んだ事が，関与して いる。また, 大きく染色体が変化する際に, 遺伝子の水平
伝搬が大きく寄与していると考兄られている（76，156）。 V. cholerae のゲノム配列から DNA 複製, 修復, 転写翻訳, 細胞壁合成, その他の中心的な分解や生合成経路の遺伝子 は, Chr1 に存在する。加えて, 細菌の病原因子に関わる 毒素共発現ピリ（TCP: toxin-coregulated pilus）, コレラ毒 素, リポ多糖, 細胞外蛋白質分泌装置の遺伝子も Chr1 に 存在する。一方, Chr2 にはプラスミドで特徵的に見られ る遺伝子捕捉系 (integron island) や宿主耽溺 (addiction) 遺伝子が存在している。また，V. parahaemolyticus の病 原性に必要な TypeIII 分泌機構に関わる遺伝子を含む pathogenicity island は, Chr2 に存在する。ビブリオ属の染 色体の大きさの多様性は，Chr2でより顕著に見られる。

\section{2 種類のべん毛をもつ海洋性ビブリオ菌}

腸炎ビブリオ菌 V. parahaemolyticus が，はじめに同定さ れたときには，単一の外膜からつながった鞘を持った極べ ん毛だけが報告されたが (112), その後, 固い寒天培地の 上では，鞘を持たない周毛性の側べん毛が生えると報告さ れた $(1,178)$ 。腸炎ビブリオ菌の近縁種である海洋性ビ ブリオ菌 V. alginolyticus でも, 極べん毛と側べん毛という 機能的に異なる 2 種類のべん毛を 1 つの菌体が持つ（図 3) (1)。極べん毛または側べん毛のみを発現する変異株（図 

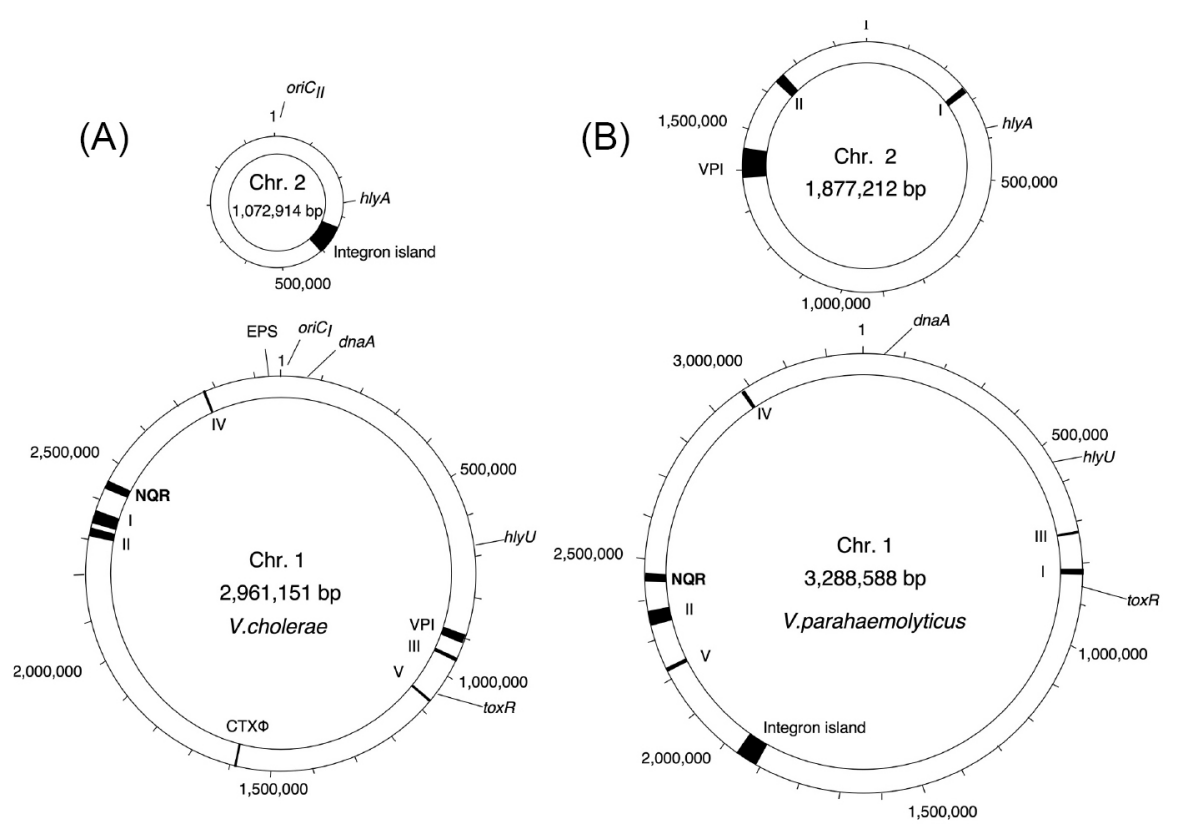

図2.・ビブリオ属菌のゲノム

V. cholerae 染色体（A）とV.parahaemolyticus 染色体（B）は，2 本の染色体からなる。サイズの大きな染色体を染色体 1 ，小さい方を染 色体 2 とした。Vibrio pathogenicity island（VPI），コレラ毒素をコードするCTX $\phi$ ファージ領域，遺伝子捕捉領域（integron island），べ ん毛遺伝子領域（染色体 1 : I, II, III, IV, V，染色体 2 : I, II)，ナトリウム輸送型 NADH- キノン酸化還元酵素領域 (NQR) を環状染色体 に打いて黒く塗った。

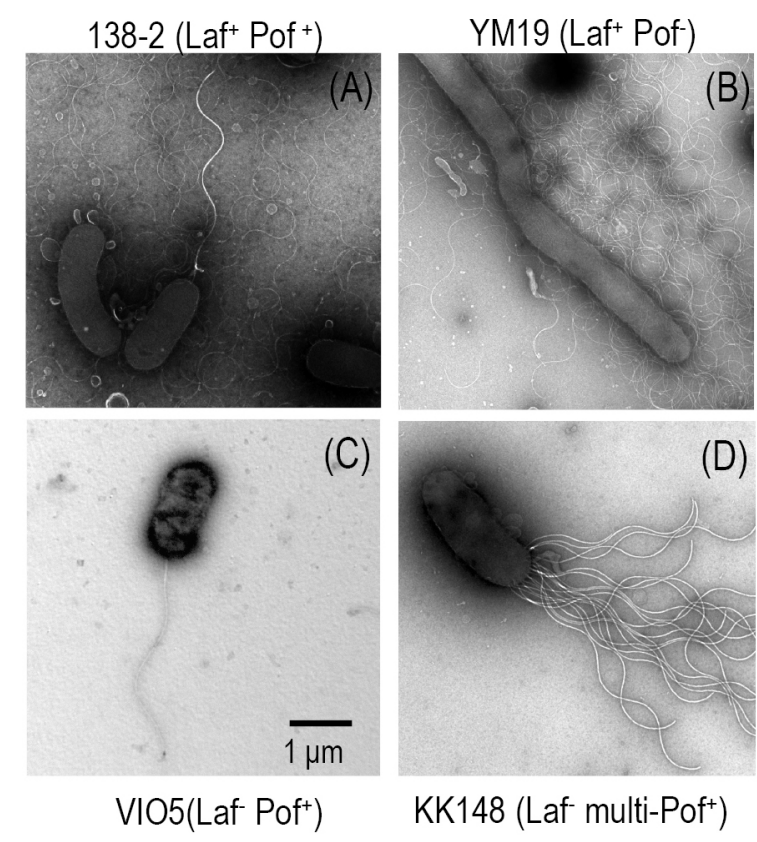

図 3. 海洋性ビブリオ菌の電子顕微鏡観察 V. alginolyticus の野生株 (138-2: A)，極べん毛欠損株（YM19: B） 側べん毛欠損株（VIO5：C), 多極べん毛変異株（KK148：D）。

3B，C）を用いて，極べん毛と側べん毛の機能的な違いが 調べられている (6)。低い粘性下では, 極べん毛による運 動により $60 \mu \mathrm{m} / \mathrm{sec} て ゙$ 遊泳できるが, 側べん毛では 20 $\mu \mathrm{m} / \mathrm{sec}$ 程度でしか遊泳できない。粘性が上がるにつれ， 極べん毛による運動能は低下し, 側べん毛による運動能は $40 \mu \mathrm{m} / \mathrm{sec}$ まで上昇し極べん毛の運動能を上回った。この ことから極べん毛は粘性の低い条件での遊泳に適してお
り，側べん毛はある程度粘性が高い条件下での運動に適し ていると考光られている。V. cholerae は側べん毛は持たず に, 極べん毛しか持っていない。側べん毛遺伝子は, Chr2 の 2 つの領域に存在しているが, 極べん毛遺伝子は, Chr1 に散在している（図 2)。

V. parahaemolyticus とV. alginolyticus に打いて, 1 つの菌 体に二種類のべん毛が形成され，機能的な違いがあること が明らかになった。一般的にべん毛運動のエネルギー源は 膜を介したプロトンの電気化学的ポテンシャル差であるこ とが明らかにされていたが，V. alginolyticus の極べん毛運 動がナトリウムイオンの電気化学的ポテンシャル差を使っ て運動することが報告された（19）。2 種類のべん毛運動の エネルギー源を調べると，極べん毛は $\mathrm{Na}^{+}$駆動力，側べ ん毛は $\mathrm{H}^{+}$駆動力によって運動することが分かった（7, 58)。極べん毛は恒常的に発現しているのに対して，側心゙ ん毛は粘性の高い条件下で発現することから，ビブリオ菌 の菌体は粘性の上昇を何らかの方法で感じていると考兄ら れ，そのセンサーは極べん毛であるといらダイナモメー タ一仮説が提案された (99)。そして, 極べん毛の $\mathrm{Na}^{+}$駆 動型モーターの阻害剤であるフェナミル（ナトリウムチャ ネル阻害剤アミロライドの誘導体）を用いた実験から，極 べん毛の回転の低下と側べん毛遺伝子の発現の間に相関関 係があることが示された。このことから極べん毛は力学的 センサーとして働き，側べん毛の発現を制御すると考光ら れている (57)。しかしながら，30 年以上も前に発見され た現象であるが，未だにどのよらにして極べん毛が粘性を 感知しているかわかっていない。 


\section{3. ベん毛遺伝子の転写制御}

細菌のベん毛構造や遺伝子は, 大腸菌やサルモネラ（ネ ズミチフス) 菌 (Salmonella Typhimurium) で最も良く研 究されている。機能や構造に必要な遺伝子構成は, どの細 菌でも基本的には良く似ているが，種によって特徵的な構 造をもつものもある。一般にグラム陰性菌のベん毛は細菌 表層膜系内に埋まった基部体（basal body）と菌体外に長 く伸びるらせん型のべん毛繊維（filament）抽び両者を つなぐフック (hook) から成っている。基部体は, 外膜 およびペプチドグリカン層に結合する LP リング, 内膜に 結合する MS リング，それらをつなぐロッドから成り立っ ている。基部体の周りにはイオンの流入と共役してべん毛 回転を駆動する膜タンパク質 MotA と MotB（ビブリオ菌 の極べん毛では, PomA とPomB と呼ばれる）からなる固 定子複合体があり, 細胞質側にはモーターの回転方向を制 御するスイッチ複合体あるいはCリングと呼ばれる構造 が MS リングの直下に存在して，その内部にべん毛タンパ ク質特異的輸送装置が存在する。これらのべん毛構造蛋白 質をコードする遺伝子やそれらの発現を調節する遺伝子が 50 個以上存在する。先にも述べたが，V. alginolyticus とV. parahaemolyticus は極べん毛と側べん毛の 2 種類のセット のベん毛遺伝子が別々に存在する（図 2）（104，183）。

ベん毛遺伝子の発現は, その構造形成と共役している。 すなわち，基部体とフックの構造が完全にできあがるまで はベん毛繊維形成や，モータータンパク質，化学感覚受容 体やシグナル伝達に関する遺伝子の発現は起こらない。こ れはべん毛の遺伝子の発現機構が厳密な階層構造をもつこ とによる。細菌のべん毛関連遺伝子に拈いては, 50 個以 上もの遺伝子がオペロンを形成し，3つあるいは 4 つのク ラスに分けられて発現制御されている(168)。サルモネラ 菌や大腸菌に扣いては, 約 50 個もの遺伝子が 17 のオペロ ンを形成している。これらのオペロンは発現の順番により 3つのクラスに分けられる（図 $4 \mathrm{~A}$ )。マスターオペロンに 属する遺伝子によりコードされる FlhD, FlhC は, クラス II に属するオペロンを活性化することにより全てのべん毛 遺伝子の発現を最上位で支配する (88)。次に，クラス II に属するべん毛特異的な $\sigma$ 因子である $\sigma 28$ (fliA) が下位 のクラスあるいは同じクラスに属する他のオペロンの発現 を正に調節する。クラス II には基部体やフックの形成に 関与する遺伝子群が属している。クラス III にはべん毛繊 維を形成するフラジェリンを含めべん毛形成の最終段階で ある䋊維形成に関与する遺伝子群や完成したべん毛の機能 に関与する遺伝子群が属している。クラス III に属する flg $M$ は, クラス II 遺伝子の下流にあるためクラス II プロ モーターからも転写を受け, fliA のアンチシグマ因子とし て働く。FlgM は FliA シグマ因子に結合し, FliA の RNA ポリメラーゼ・コア酵素への結合を阻害することでクラス III 遺伝子群の発現を負に制御する。フックが完成すると, FlgM はフックおよび基部体構造の中を通って菌体外に排
出され, その結果, 細胞内の FlgM 濃度が減少し FliA が 活性化されてクラス III の発現が開始されると考光られて いる $(83,123 ， 171)$ 。ベん毛形成に拈ける遺伝子発現調 節の要は，間違いなく FliA-FlgM システムであるといえる だろら。しかし，これだけでは複雑な構造体ができあがる メカニズムは説明できない。FliA と FlgM の調節系以外に も, ベん毛特異的シャペロンによる発現の調節機構が明ら かになっている。クラス III プロモーターからの flgM 遺伝 子 mRNAの翻訳には, HAP（フック付随タンパク質： FlgK, FlgL, FliD）のシャペロンである FlgN が必要である。

\section{(A) S. Typhimurium 周ベん毛遺伝子}

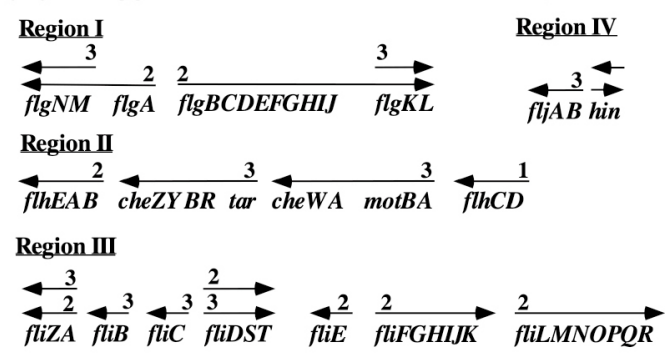

(B) V. cholerae 極べん毛遺伝子

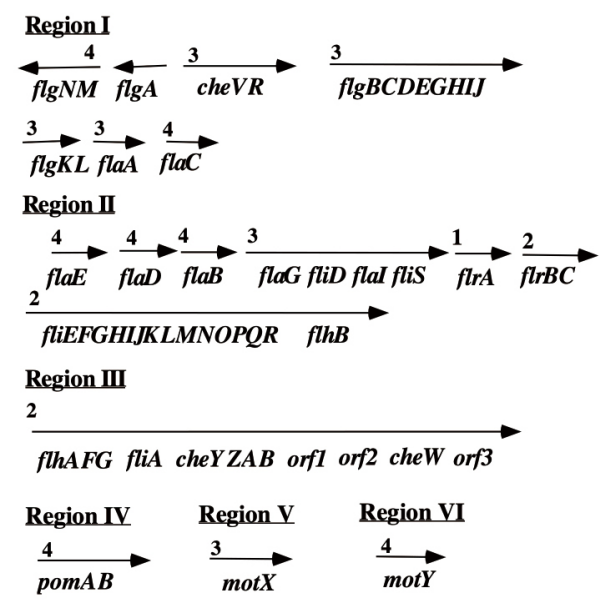

(C) V. parahaemolyticus 側べん毛遺伝子

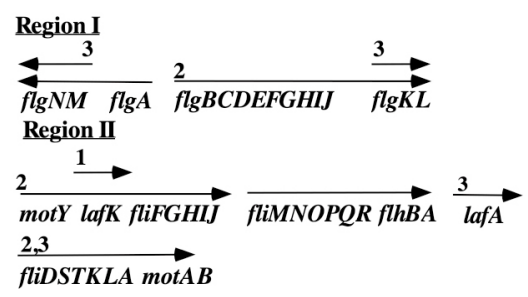

図 4. ベん毛遺伝子の構成

S. Typhimurium のプロトン駆動型である周べん毛(A),V. cholerae のナトリウムイオン駆動型である極べん毛 (B), V. parahaemolyticus のプロトン駆動型である側べん毛 (C), そ水 らの遺伝子構成を示す。遺伝子名の上に書かれた矢印は転写ユ ニットを示し，その矢印の始まりの数字は転写階層の順番を 示す。S. Typhimurium のベん毛遺伝子は, 染色体の 4 つの領域 (region I, II, III, IV) に分布し, V. cholerae の極べん毛遺伝子は, 染色体 1 の 6 つ領域（region I, II, III, IV, V, VI）に分布する。V. parahaemolyticus の側べん毛遺伝子は，染色体 2 の 2 の領域 (region I, II) に分布する。S. Typhimurium とE. coli のべん毛遺伝 子，またはV.alginolyticus, V. parahaemolyticus とV. cholerae の極 べん毛遺伝子の構成は浪添等しい。 
フックの形成に伴い HAP が輸送されると, FlgN は単体に なる。この単体 FlgN がクラス III からの FlgM の発現を促 す。発現した FlgM はそのまま輸送されるが，このときク ラス II から発現し細胞内で FliA シグマ因子に拮抗してい た FlgM も FlgN により輸送されると考兄られる。結果と して細胞内の FlgM 濃度が低くなり, FliA がシグマ因子と して機能して，フラジェリンなどクラス III 遺伝子からの 発現を活性化するのである。フックが完成しフィラメント の合成が始まると，フック系の基質は輸送されなくなり細 胞内にとどまることになる。すると，FlgN はHAPのタン パク質と結合しシャペロンとしての機能に戻るため, クラ ス III からの FlgM の発現及び輸送が行わ机なくなる (55)。 このように抗シグマ因子 FlgM の発現，輸送が調節される ことによって, FliA-FlgM のシステムは維密に制御されて いるのである。また，フラジェリンのシャペロンである FliS は FlgM の輸送を負に制御することが発見されている (181)。その他，FliT と FliZ が，クラス II プロモーターか らの転写の負と正の制御因子であることが推定されている (82)。べん毛レギュロンの一番上位の制御因子 FlhD-FlhC が ATP 依存プロテアーゼの一種である ClpXP により分解 制御を受けていることが示されて，べん毛の発現制御の新 たなグローバルな側面が明らかにされている（171）。

V. parahaemolyticus と V. cholerae の極べん毛遺伝子の発 現制御が推測されている（図 4B）（28，104，155）。V. cholerae では, オペロンの発現の順番により 4 つのクラス に分けられて，オペロンの転写制御のモデルが出されてい る $(21,136) 。 \operatorname{pom} A B$ や $\operatorname{mot} X$ のモーター遺伝子やフラジェ

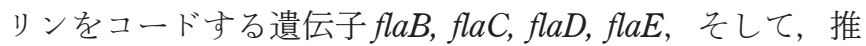
定抗 $\sigma$ 因子をコードする $f l g M$ を含むオペロンは， $\sigma 28$ 型 のプロモーター配列を持ち, fliA 遺伝子のコードする $\sigma 28$ に依存して発現することが確認さ扎ている。こ北対して, コアフラジェリンをコードする flaA やモータータンパク 質をコードする MotY とフック基部体の構造遺伝子や HAPs などは, FlrC と 054 に依存した発現を示す。最初に 転写されるのはflrA であり，その産物である FlrA と $\sigma 54$ がクラス II オペロンの転写を起こす。FlrB のリン酸基が FlrC に転移され，活性化される。V.parahaemolyticus の極 べん毛遺伝子も，遺伝子名は異なってつけられているが $V$. cholerae と同様な転写制御によって調節されていることが 分かっている $(62 ， 103)$ 。ビブリオ属の極べん毛制御は, 同じ極べん毛をもつシュードモナス属のべん毛遺伝子の制 御機構と類似している (150)。V.parahaemolyticus の側べん 毛遺伝子の転写制御も解析さ水，階層的に制御されている ていることが分かっている（図 4C)。面白いことに，周毛 性のV. parahaemolyticus の側べん毛遺伝子のマスター制御 遺伝子は $\sigma 54$ タイプであるが，下流は大腸菌のもつ $\sigma 28$ 型に近い制御因子が働いている (153)。

\section{4. ビブリオ菌べん毛の数と位置制御}

ベん毛の数や位置を制御するのは非常に重要なことであ
る。海洋性ビブリオ菌やコレラ菌，緑膿菌は極に 1 本のベ 几毛を持ち，べん毛の形成位置や本数制御おいて，類似の 制御機構を持つことが報告されている。べん毛の形成位置 と本数に関する遺伝子が, シュードモナス属で同定された。 P. putida では FlhF がべん毛形成位置決定に関与し, FleN がべん毛の本数制御に関わっていることが報告され (134), FlhF 欠損株は極以外飞もべん毛を形成すること, $P$. aeruginosa では FleN (V. alginolyticus のホモログは FlhG) 欠損株が多数のべん毛を持つことが報告されている(23)。 また，V. alginolyticus の FlhF と FlhG についての研究が行 わ狆，緑膿菌と同様に $f l h F$ 欠損株は極べん毛を持たず， $f l h G$ 欠損株は極に多数のべん毛を持つことが報告されてい る（図 3D）（81，80）。これら報告の中で，FlhF を大量発 現させると極べん毛の数が増光，FlhG を大量発現させる とべん毛の数が減るといらこと，また，FlhF と FlhG の共 発現は FlhG 単独で発現したときよりもべん毛数を劇的に 減少させ，変異体解析から FlhF の GTP 結合ドメインがべ 几毛の位置制御に重要であることが示されている。コレラ 菌でも FlhF と FlhG（FleN）について研究が拉こなわれ， FlhF はクラス 3 遺伝子の発現を促進するため, ベん毛本 数を増加させ, FlhG はフラジェリンなぞの遺伝子の発現 を抑制し，べん毛本数を減少させることが報告されている (22)。さらに，V. cholerae そ执いて FlhFへの GTP 結合が べん毛形成に影響を与えるが，FlhFの GTPase 活性はべ 几毛形成機能に必須ではないことが示されている $(38) 。 V$. alginolyticus でも FlhF の GTPase モチーフは重要であるが, GTPase 活性を失った変異体でも，べん毛形成には異常は 敃きないこと，そして FlhF の GTPase 活性は FlhG によっ て促進されることが示されている（74，75）。また，FlhG においても ATPase モチーフは細胞内での局在の制御に重 要であるが，ATPase 活性がなくても，FlhF の抑制活性は あることが示されている（130）。FlhF は，GTPase 活性に 共役し生合成されたタンパク質の膜透過に㗢くシグナル認 識粒子 (SRP) の Ffh や SRP 受容体の FtsY と相同性があり, FlhG は ATPase 活性を持つ細胞分裂制御因子の MinD と相 同性がある。しかし，FlhF, FlhG の酵素活性とその局在が ぞのようにべん毛の数と形成位置を制御しているかは解明 されていない。in vitro で酵素活性や機能を明らかにする ために，V. alginolyticus の FlhG が大量発現系で精製されて いるが，低い塩濃度で凝集しやすくなり，ATP 依存的に その凝集が押さえられることが明らかとなり，ATP 結合 による FlhG の構造の大きな変化が推測されている（69）。 以上のことから，べん毛の数は FlhF によって正に FlhG によって負に制御され，また FlhF と FlhG が協同して働 くことでべん毛形成が正確に制御される。そして，FlhF は菌体の極に局在して，べん毛の形成位置を同時に制御し ていると考光られている（図 5）（81）。

FlhG と FlhF 以外飞るべん毛の本数と形成位置を制御す る遺伝子が見つかっている。FlhF と FlhG が欠損した株か ら，極べん毛が菌体の周囲に形成され運動能を回復した抑 


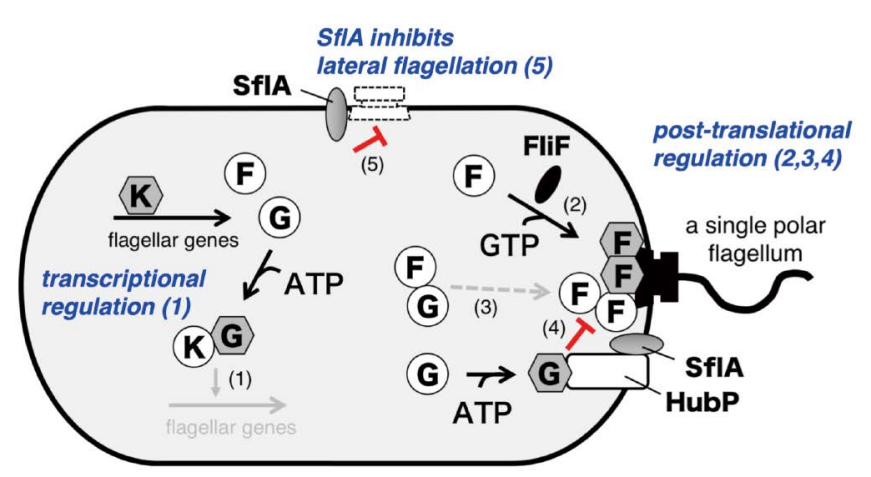

$$
\begin{array}{llll}
\text { F inactive FlhF } & \text { (G) inactive FlhG } & \text { K inactive FlaK } \\
\text { F active FlhF } & \text { G } & \text { active FlhG } & \text { K }
\end{array}
$$

図 5. ビブリオ菌の極べん毛の位置と数の制御モデル ベん毛構成タンパク質が十分に合成されると, FlhG はマスター レギュレーターFlaK に作用して，極べん毛遺伝子の発現を低下 させる。これによって，余分なタンパク質合成を抑制する。 FlhF はGTP と結合してホモダイマーを形成し，菌体の極に局在する。 FlhF は, MS- リング構成タンパク質 FliF の極でのリングの形成 を促進する。FlhG は ATP と結合して, FlhF の極での促進活性を, HubP 依存的に抑制する。一方，SflA は，FlhF が久損していると MS-リング形成を阻害する。SflA と FlhG は HubP 依存的に極に 局在できる。総説（73）から引用した。

圧変異体が得られた（67）。極べん毛性の菌を周毛性に変 換できたことになり，この変異体に扔いては，べん毛形成 開始が菌体のどこにでも起こることができるよらになった と考光られる。この抑圧変異の原因が，染色体ゲノム配列 を決定することで， sflA という遺伝子の欠損であることが 示された（64）。SflA は，1回膜貫通タンパク質で，細胞外 ドメインに TPR (tetratricopeptide repeat) モチーフをもち, 細胞質領域に DnaJ ドメインを持ち，極以外からのべん毛 形成を阻害すると推測されている。細胞外ドメインは構造 決定され，何らかのシグナルを受け取っていると考光られ ているが，どのよらに機能しているのかは不明である (142)。

V. alginolyticus では，hubP を欠損すると極べん毛が多毛 になることが報告されている（160）。HubP はV V cholerae で 1 回膜貫通型の極局在タンパク質として存在が明らかと なった (179)。HubP は，すべてのビブリオ属，フォトバ クテリウム属，抢よびその他のいくつかの $\gamma$ プロテオバク テリアで保存されている。HubPの $\mathrm{N}$ 末端と $\mathrm{C}$ 末端は, 緑 膿菌の IV 型線毛の形成に対する正の調節因子である FimV と類似している (176)。HubP には，N末端側にペリプラズ ムペプチドグリカン結合モチーフ (LysM)，C 末端側に絽返 し配列を含む大きな細胞質側領域がある。LysM ドメイン は HubP の極局在に重要であり, 細胞質領域で ParA 様夕 ンパク質（ParA， ParC， FlhG）と相互作用することが示さ 孔ている (179)。HubP は，染色体分配と走化性受容体の 配置に関与していることが示唆されていたが，V. cholerae では，べん毛の数は hubP を欠損しても注とんぞ影響が なかった（179）。Shewanella putrefaciensでも, HubPがV. cholerae と同様の役割を持つことが示唆されている (139)。
V. alginolyticus では, hubP 欠損で SflA と FlhG の極局在が 失われることが示されている $(48,160)$ 。SflA と FlhG が ベん毛の形成を抑元る働きがあることを考光ると，これら 2 つのタンパク質の阻害機能の強さを調節しているのではな いかと想像される。まとめると，V. alginolyticus 極べん毛の 数と位置の制御には，FlhF，FlhG，HubP，SflA が主に関 与していることが示され，モデルが提案されている（図 5)。

\section{5. ベん毛繊維タンパク質フラジェリン}

多くのビブリオ属菌において，極べん毛は少なくとも 2 種類のフラジェリンから構成されていることが知られてい る。V.parahaemolyticus では，極べん毛のフラジェリンを コードする遺伝子 flaA flaFの 6 つが同定され，5つのオ

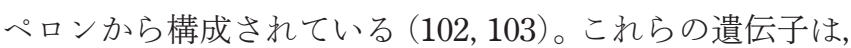
染色体上でflaFAB (Region II) 沶よびflaCDE (Region I) の 2 つ領域に分かれている。flaA, flaB 打よびflaD は, $\sigma 28$ 型のプロモータ一配列を持ち大腸菌において 628 を コードするfliA 遺伝子に依存して発現することが確認され ている。こ机に対して, flaC の発現は, fliA には依存しない。 $f l a C$ は $\sigma 54$ 型のプロモーターを持つが， $\sigma 54$ を欠損した大 腸菌の菌体中でも発現をすることが確認されている (152)。flaAB 部位の下流飞は, flaG, fliD, flaI, fliS, flaK $(f l r A)$ が存在する。FliS はフラジェリン遺伝子の発現調節 に関係し，FliKは， 054 を含む RNA ポリメラーゼのアク チベーターして働く NtrC，NifA 等のホモログである。 $f l a C$ の発現には, fliS と flaK の両方が必要であるのに対し て, 他のフラジェリン遺伝子の発現には, fliS は必要だが flaK は必要でない。fliD は HAP2（べん毛繊維キャップタ ンパク質)，flaI はロッド（Rod）タンパク質のホモログを それぞれコードしているが，flaGは $15 \mathrm{kDa}$ の機能未知の タンパク質をコードする。また，V. alginolyticusの $\sigma 54$ RNA サブュニットをコードする $r p o N$ 遺伝子がクローニン グされ，極べん毛遺伝子の発現汇関わっていることが，直 接的に示されている (59)。V. cholerae でも極べん毛では, 5 種類のフラジェリンが同定されて招り，同様な制御を受 けていることが示されている $(28 ， 65)$ 。

\section{6. ベん毛形成}

ベん毛の構造は，基本的には膜に埋まったべん毛の基部 構造（Basal body）に，その根本から先端に向けて構築さ れていく。この構築の基本的なスキームは, サルモネラ菌 の多くの変異体の構造解析から, 単純なものから複雑な構 造が作られていくといら流孔で作られた（154）。基本的な ベん毛の構造形成については, サルモネラ菌のべん毛で研 究が進んでいる（図 6A）（93）。まず始めに FliF から成る MS-リングが作られ，膜に埋め込まれて構造形成が開始さ れると考光られている (42)。MS-リングは基部体の中心と なる構造でべん毛形態形成の最初の段階で電子顕微鏡によ り観察される（77）。6 $65 \mathrm{kDa}$ の一種類のタンパク質からで きているにもかかわらず 2 枚のリング構造を作るような複 


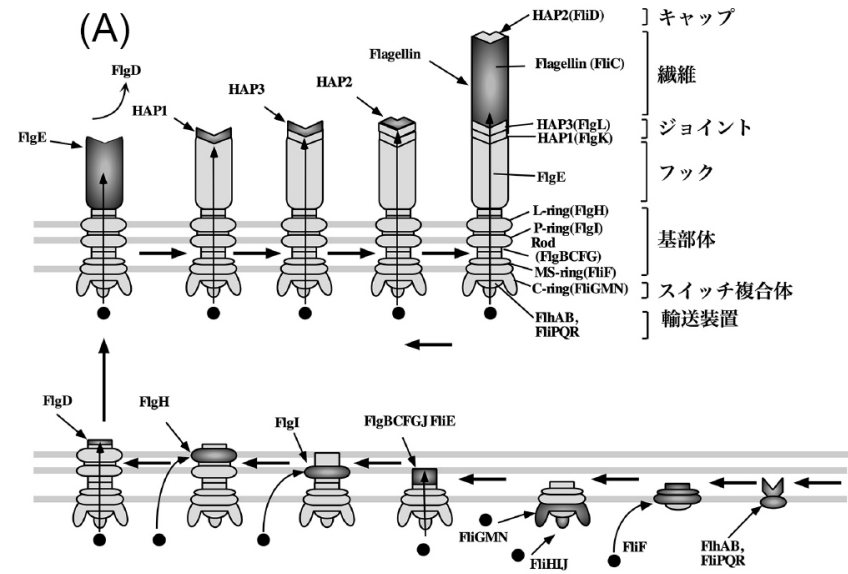

(B)

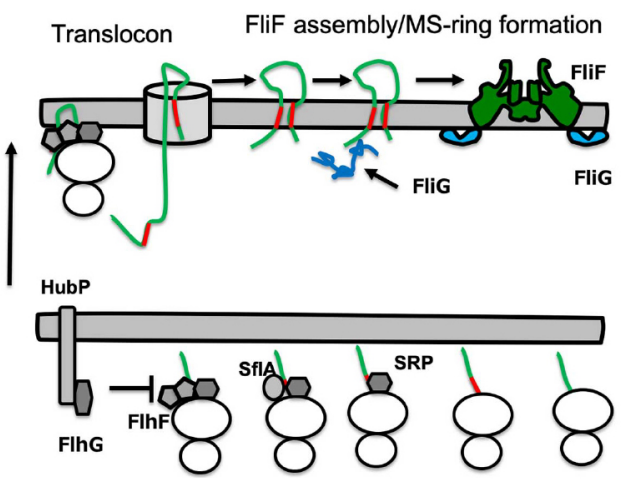

図6. 細菌べん毛の形態形成モデル

(A) サルモネラ菌で得られているべん毛形成スキームを総説 (93, 168）の図を参考に記載した。形成のモデルは，構造が単純なも のから複雑なものまで構築されているといら仮定に基づいて作成 されている。べん毛の形態形成は, FliF が膜に組み込まれりング 形成することから始まると考光られているが, TypeIII 輸送体コ アから形成されるといらモデルも提案されている（78）。（B）ビ ブリオ菌 FliF の MS- リング形成モデル。2 回膜貫通タンパク質 FliF の $\mathrm{N}$ 末側の $\mathrm{TM}$ が合成されると，シグナル認識粒子（SRP） が結合する。この状態の結合は, 効率的に Secトランスロコンへ の受け渡しができない。ここに，FlhF が作用することによって， FliFを Secトランスロコン効率良く挿入して, FliF の膜通過を可 能にする。ただし，一般的に大きな膜タンパク質はSecトランス ロコンを介して細胞膜に挿入されると考兄られているが, FliF が Secトランスロコンを介しているといら証拠はない。膜挿入され た FliF は FliG と相互作用することによって，リング形成が促進 される。寺島らの論文（165）を参考に描いた。

雑な形を FliF がとると考えられていた（173）。この複雑な 構造がクライオ電子顕微鏡によってサブアトミックレベル で解かれた (53)。In vitroで大量に FliFを発現させると MS-リング形成は起こると思われるが，in vivo では FliP, FliQ, FliR といら 3 つのタンパク質から成る TypeIII 輸送 体のコアの周りに FliF が集合して MS-リングとなるモデ ルも出されている(78)。輸送を担う FlhA と FlhB 膜タン パク質の FlhB の膜貫通領域が FliPQR のコアに巻き付い ている構造も出されている(79)。MS-リングが形成される と, その下に FliG, FliM, FliN という 3 種のタンパク質 からなるスイッチ複合体と呼ばれるリング状構造（C-リン グ）が作られる（32）。MS-リングを構成している FliF の C 末端とC-リングを構成している FliG の N 末端が相互作 用してリング構築されると考光られている $(90 ， 122)$ 。 イッチ複合体の遺伝子欠損によりこれ以降の構造が作られ
ないことから，スイッチ複合体はべん毛回転の向きを変化 させる機能のみでなく、べん毛構造を構築する上で重要な 働きをもつ。C-リングについては，回転子として第8 章で 詳しく取り上げる。

べん毛構造の大部分は細胞膜より外側に位置しているの で多くの部品は細胞膜を透過しなければならない。ほとん ぞのべん毛タンパク質は，Sec系膜透過装置により認識さ れるシグナルペプチド配列を持たず，べん毛特異的なチャ ネルにより運ばれる (92)。ベん毛繊維やフックの中心部 にある中空構造がそのチャネルとなる (114)。べん毛の分 泌輸送装置は，細菌の病原因子の TypeIII 輸送装置と相同 性があることが分かっている。チャネルの入り口にはべん 毛タンパク質を特異的に選択し輸送するべん毛輸送装置が 存在し, FlhA, FlhB, FliP, FliQ, FliR の 5 種の膜タンパク質 と FliH，FliI，FliJの 3 種の細胞質タンパク質により構成 されている(109)。輸送装置の構造もクライオ電子顕微鏡 によって構造が明らかにされつつある $(26,78)$ 。輸送基 質としてフラジェリン (FliC), HAPs (FliD, FlgK, $\mathrm{F} \operatorname{lgL})$ ，抗シグマ因子 $(\mathrm{FlgM})$, フックタンパク質 $(\mathrm{FlgE})$, フックキャップタンパク質（FlgD）などがある。基質に はフラジェリン型とフック型があり，基質に対応したシャ ペロン（FlgN，FliT，FliS）が細胞内で識別し，輸送装置 に運び分泌される $(33 ， 61)$ 。FliI は $\mathrm{F}_{0} \mathrm{~F}_{1}$-ATPase の $\beta$ サブ ユニットの活性部位と相同性があり, ATPase 活性も実際 に確認されている。また，FliH は FliI と複合体を作り， その ATPase 活性を抑制している。この複合体が FlhA, $\mathrm{FlhB}$ と相互作用して基質を膜に挿入していくと考光られ ている (106)。効率的な輸送にはATP のエネルギーとプ ロトン駆動力が必要なことが示されている（110，135）。 最近では, in vitro の輸送系の再構成によって, ATP 加水 分解エネルギーとプロトン駆動力のぞちらか片方のエネル ギーさえあれば輸送が起こることが明らかにされた (166)。TypeIII による輸送では，分泌基質はタンパク質の $\mathrm{N}$ 末端(もしくは mRNA の 5 末端) に分泌シグナルを持ち, また C 末端側へシャペロンが結合することにより分泌が 制御されている $(30,108)$ 。輸送基質である FlgK (HAP1), FlgL (HAP3) とこれらの特異シャペロンである FlgN と の間には直接の結合が観察され，その相互作用には $\mathrm{C}$ 末 端が必要であることが示されている（61）。シャペロンが 結合することで分泌タンパク質の分解が防がれていると考 えられるのだが, FlgNがシャペロンとして働き，リプレッ サータンパク質の分泌を制御することによって, タンパク 質合成を制御するといら新しい面が見つかった（55）。Mリングの内側にべん毛特異的輸送装置が配置されるとべん 毛タンパク質の輸送が始まる。 FlgJ がロッドキャプタンパ ク質となって，FlgB，FlgC，FlgG，FlgF，FliE がロッド を形成する。しかしロッドの成長は，拈そらくペプチドグ リカン層の障害のために，すぐに止まる。そこで，ムラミ ダーゼ活性を持つ $\mathrm{Flg} J$ がペプチドグリカン層に孔をあけ, ロッドの形成を助ける（115）。その後，ペプチドグリカン 
層に FlgA がシャペロンとして働いて P-リング（FlgI）が 形成され，さらに外膜に L-リング（FlgH）が形成され, これらを貫通する形でロッドが完成する。FlgI と FlgH は 他のベん毛タンパク質とは異なり，シグナルペプチドをも ちSec 系膜透過装置に依存して分泌される(91)。ロッド が完成すると，先端へのフックの重合が始まるが，これに はフックキャップタンパク質と呼ばれる FlgD が重要な役 割を持つ。FlgD は伸長するフックの先端飞位置し, 重合 の間, フックタンパク質 $\mathrm{F} \operatorname{lgE}$ は FlgD のキャップの下に 挿入される。フックが完成すると, FlgD は FlgK といら別 のタンパク質に置き換わる（124）。FlgK は HAP1（hook associated protein 1）ともよばれ, HAP3（FlgL）と共にフッ クとべん毛纎維の間をつなぐ (44)。サルモネラ菌では, ベん毛繊維は 1 種類のフラジェリンタンパク質 (FliC) か ら成る。フラジェリンモノマーは, in vitro では自己重合 できるが，in vivoでの重合には HAP2（FliD）とよばれる キャップ構造が必要である (43)。フックの場合と同様に, フラジェリンはHAP2 のキャップ構造の下に重合される。 HAP2 の欠失変異株では，フラジェリンモノマーは重合で きずに培地の中に放出される。HAP2 はフックのキャップ である FlgD とは異なり, べん毛の先端に構造として残る。 電子顕微鏡に上る先端 HAP2 の微細構造から, フラジェリ ンと相互作用しながら, HAP2 キャップが回転し，その先 端にフラジェリンを重合させていく様子がモデル化されて いる (182)。最近, HAP2 の結晶構造も決定され，原子構 造から重合過程が考察されている(149)。

ビブリオ菌とサルモネラ菌でのべん毛基部構築で，大き な違いが見いだされている。サルモネラ菌の FliF は，先 にも述べたが，単独で大腸菌で大量発現するだけで MS-リ ングは構築される $(173)$ 。として, クライオ電子顕微鏡で の構造解析がサブアトミックレベルで成功している (53)。 V. alginolyticus の FliF を大腸菌で大量発現しても，MS-リ ング構造を全く作らない (122)。べん毛形成でサルモネラ 菌や大腸菌と大きく異なる点として, 第 4 章でも述べたが, ビブリオ属の極べん毛形成には, FlhF を要求する。FlhF がどのようにべん毛形成に関与しているのかは分かってい ない。しかし，V.alginolyticus の FliF を $\mathrm{FlhF}$ とともに大量 発現すると, 大腸菌中での MS-リング形成が格段に上昇す る。この MS リング促進効果は, C-リングの構成タンパク 質である FliG との共発現に扔いても観察された。FliGが FliF のリング形成に必要であるといらことが，サルモネラ 菌や大腸菌の FliF 研究からも明らかにされている (86, 113)。しかし，この大腸菌中での MS-リング形成には, FliPQR と FlhAB からなる TypeIII 輸送体コアを必要とし ないらしい。ただし，FliF が過剩発現した状態ではリング 形成が起こるが，菌体に扮ける通常のべん毛形成時には， FliPQR が核になって MS-リング形成するモデルも提案さ れている (78)。これまでの得られている結果から, ビブ リオ菌の極べん毛形成に扔いては, FlhF がシグナル認識 粒子（SRP）である Ffh や SRP 受容体の FtsY と相同性が
あることを考兄合わせ，FlhF が FliF の膜挿入をアシスト し，膜挿入さ机た FliF のリング形成を FliG が促進してい るというモデルが提案されている(図 6B)。

ビブリオ属菌の極べん毛の基本的な構造は，サルモネラ 菌や大腸菌のべん毛と同じである。大きく異なる点は，ビ ブリオ属菌の極べん毛は，外膜からつながった鞘に覆われ ている点である (20)。そして，H-リング，T-リングと呼 ばれる 2 つリング構造が，LP-リング構造の外側に存在 することである（図 7)。極べん毛の早い安定な回転のた めに必要な構造であろうと推測されている。 H-リングの 主要な構成タンパク質が FlgT と FlgO であることが示さ れ，H-リングを欠損するとべん毛繊維が外膜を押し上げ て鞘を持ったべん毛にならずに，スピロへータのべん毛の ようにペリプラズムにべん毛緘維が構築してしまう （187）。ビブリオ菌極べん毛基部体とモータ一部分の構造 がクライオ電子顕微鏡で解析され，まだ，サブアトミック レベルの解析までは到達していないが，近い将来，菌体乞 のままで構造解析が行われることが期待される(図 7A)。 さらに，サルモネラ菌では遺伝子変異体から基部体を精製 してその構造形成が調べられたが，V. alginolyticus では経 時的に直接クライオ電子顕微鏡で菌体にあるべん毛基部体 を観察することで，べん毛基部体の中間体の観察に成功し ている（188）（図 7B）。な抢カウロバクタ一菌 (Caulobacter crescentus）では知られていたことだが，最近ビブリオ菌 のべん毛が培養条件によって，LP-リング構造を残して抜 けることが報告されている $(31 ， 190)$ 。

\section{7. 細菌ベん毛モーター固定子}

初めに述べたようにV. alginolyticus と V. parahaemolyticus の極べん毛は, $\mathrm{Na}^{+}$駆動力により回転することが知られて いた。 $\mathrm{H}^{+}$駆動型モーターの遺伝子は，既に大腸菌などで $\operatorname{mot} A$ と motB がクローン化されていた (24)。当時, $\operatorname{mot} A$ あるいは motB の塩基配列の相同性からハイブリダイ ゼーションなどによって $\mathrm{Na}^{+}$駆動型モータ一の遺伝子の クローン化が世界で必死に行われていた。ところが，V. parahaemolyticus から $\operatorname{mot} X$ と $\operatorname{mot} Y$ 名付けられた遺伝子 に変異が生じると，極べん毛の形成には影響しないが, 回転はできなくなるといら現象が確認された（100，101）。 V. alginolyticus からも同様な遺伝子が, 我々の研究室で クローン化された $(125 ， 129)$ 。MotX と MotY は，当初は 両タンパク質ともに 1 回膜貫通型タンパク質で，この $2 つ$ が $\mathrm{H}^{+}$駆動型モーター遺伝子と相同性はないが， $\mathrm{Na}^{+}$駆動 型モータ一遺伝子であると信じられていた。しかし，我々 の研究室で海洋性ビブリオ菌 $V$. alginolyticus の運動能欠損 株の運動を相補する遺伝子を同定すると， $\mathrm{H}^{+}$駆動型モー タ一遺伝子 $m o t A$ 打よび $m o t B$ と相同性のある遺伝子 (pomA 打よびpomB と命名)を得ることに成功した (3)。V. parahaemolyticus からもすぐと, pomA と pomB に相同な遺 伝子がクローン化された（51）。それぞれ 4 回膜貫通型，1 回膜貫通型の PomA，PomB に加光，MotX，MotY の 4 つ 
(A)

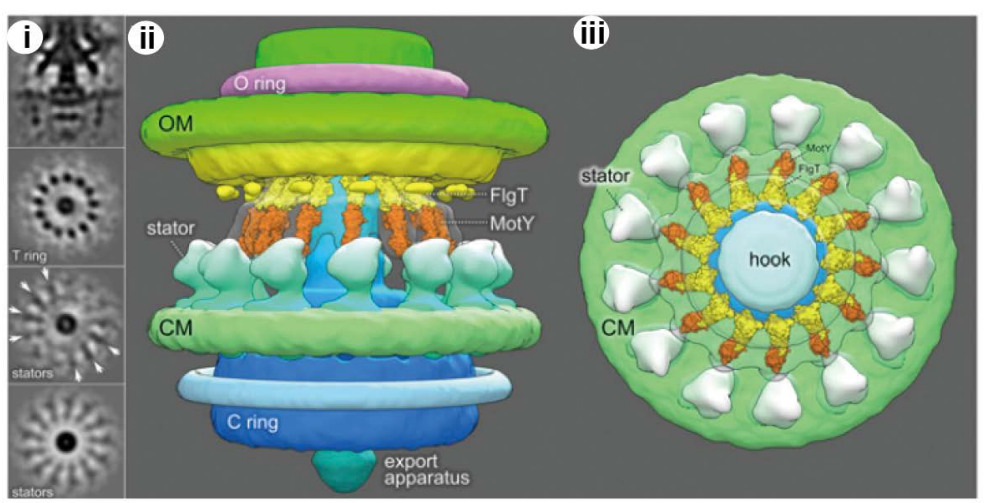

(B)

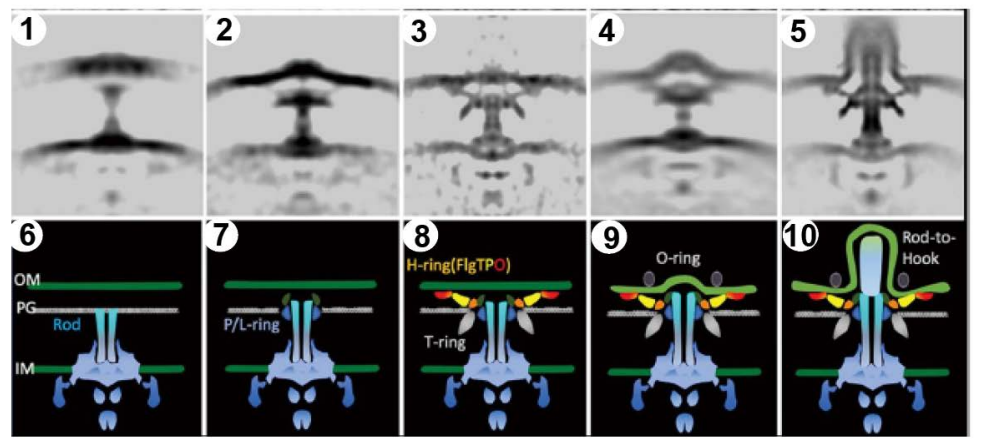

図 7. ビブリオ菌極ベん毛のモーター構造

(A) ビブリオ菌極ベん毛のクライオ電子顕微鏡観察によるべん毛モーター構造を論文 (186) から引用した。（i）野生型モータ一の平均像。 第 1 パネルは中央部の断面，第 2 パネルはT-リングから見た断面，第 3 パネルは，細胞質膜（CM）の上部での断面，第 4 のパネルは， 第 3 のパネルの 13 回対称性を適用した後の断面である。ビブリオべん毛モータ一の全体構造を示す側面から見た像（ii）及び上から見 た像（iii）を示す。(B) クライオ電子顕微鏡観察により経時的に構造形成を観察した結果を論文（188）より引用した。最初に P/L-リ ングが形成され，次に MotX と MotY からなるビブリオ特異的な T- リングが形成され，FlgT，FlgP，FlgO が集合して H- リングが形成 される。O-リング形成によりロッドからフック形成するための準備が整ったことになる。3Dトモグラムの代表的なスライス図 (Stage_1 からStage_5 まで）を作り，べん毛構造形成中の異なるステージのサブトモグラム平均構造の中央部を示す $(1 \sim 5)$ 。パネル 1 亿 5 示 されている構造のモデル図 $(6 \sim 10)$ 。

のモータータンパク質がビブリオ菌の $\mathrm{Na}^{+}$駆動型モーター の回転に必要であることが明らかとなった。PomA は 2 番 目と 3 番目の膜貫通領域間に大きな細胞質ループ領域が存 在し,このループ領域が回転子構成タンパク質 FliG と相 互作用すると考光られている（159，184，185）。

MotA/B のオーソログである PomA/B 複合体は，ビブリ オ菌などの $\mathrm{Na}^{+}$駆動型べん毛モーターのイオン透過と共 役したトルク発生ユニットである。膜タンパク質である PomA/B 複合体を, 界面活性剂を用いて可溶化して精製す ると, $\mathrm{A}_{4} \mathrm{~B}_{2}$ のへテロ六量体を形成していると推測された (147)。はじめは，このストイキオメトリーが信じられて いたが，最近のクライオ電子顕微鏡による構造解析から $\mathrm{A}_{5} \mathrm{~B}_{2}$ の構造をとると改訂された $(25,143)$ 。PomA/PomB 複合体をりポソームに再構成し, カリウムイオンにより拡 散膜電位を形成させると，プロテオリポソーム内にナトリ ウムイオンを取り込むことから, PomA/PomB 複合体がナ トリウムイオン透過活性を持つことが示された（146）。た だし，この in vitro 再構成系の追試実験が行われているが， その再現性は得られていない。しかしながら, 大腸菌に PomA/PomB 複合体を発現させた生細胞を用いた実験によ り, ナトリウムイオンが透過することを実証している
(162)。共役イオンは PomA/PomB 複合体が形成するイオ ンチャネルを通り, 細胞内に流入し, それと共役して PomA の細胞質ループ領域と回転子構成タンパク質の FliG との間に何らかの相互作用が起こり, 回転力に変換される と考えられている。PomB は $\mathrm{N}$ 末端に 1 回膜貫通領域を持 ち, 残りの大部分がペリプラズム空間に存在している。こ のペリプラズム領域には, ペプチドグリカン結合モチーフ が存在し, PomA/PomB 複合体をペプチドグリカン層にア ンカーしていると考光られている。また，少なくとも 10 個以上の PomA/PomB 複合体が回転子の周りを取り囲むよ らに存在し, 回転子のタンパク質と相互作用してステップ 状に回転していると考えられている(151)。

エネルギー変換体である MotA/MotB または PomA/PomB 複合体を構成する MotB と PomB のペリプラズム部分の構 造については，二量体として結晶構造解析に成功している (68，140，189）。膜貫通領域の $\alpha$-helix からつながってい るだろらと思われる $\alpha$-helix が OmpA 様構造をもつぺプチ ドグリカン結合ドメインを挟むよらにして二量体を作って いる。そして， N 末端側の $\alpha$-helix の先に細胞膜があると すると，この折りたたまれたぺリプラズム部分がペプチド グリカンに結合するには遠すぎると考えられた。実際に N 
末端側の $\alpha$-helix の構造が変化してペプチドグリカンと相 互作用出来るよらになることが示されている（図 8A）(72, 189）。固定子の膜貫通領域の構造は, 分子動力学シミュ レーションによって推測され，イオン透過のモデルが提案 されている（図 8B）（116，131）。エネルギー変換体であ る PomA/PomB 複合体構造解析は世界中で試みられていた が成功していなかった。しかし，最近，クライオ電子顕微 鏡を用いて，全体構造ではないが，一番主要なイオン透過 部位と細胞質領域の構造が決定され，A サブュニット5 分 子がリングになった構造に二量体の B サブユニットの膜 貫通領域が軸になるように構築されているモデルが提出さ れた $(25,143)$ 。MotA/MotB と相同性がある ExbB/ExbD エネルギ一変換体の構造が決定されて抢り，その複合体は

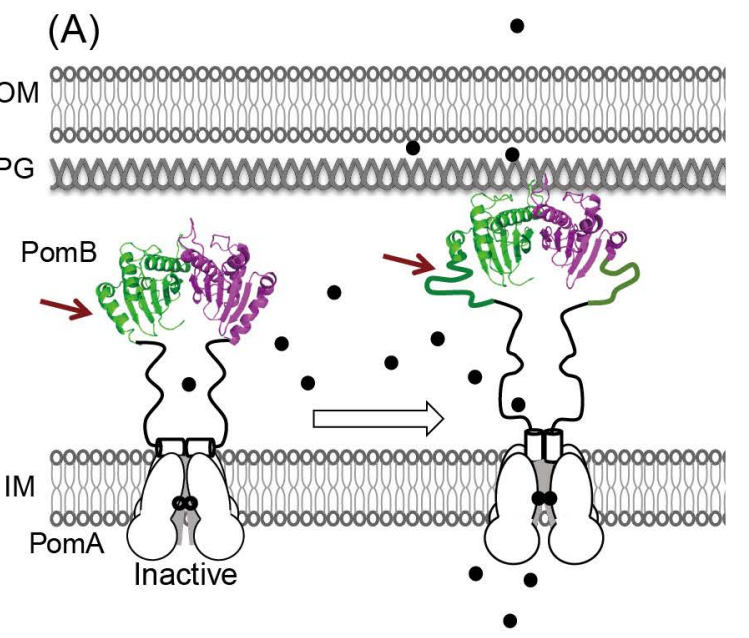

(B)

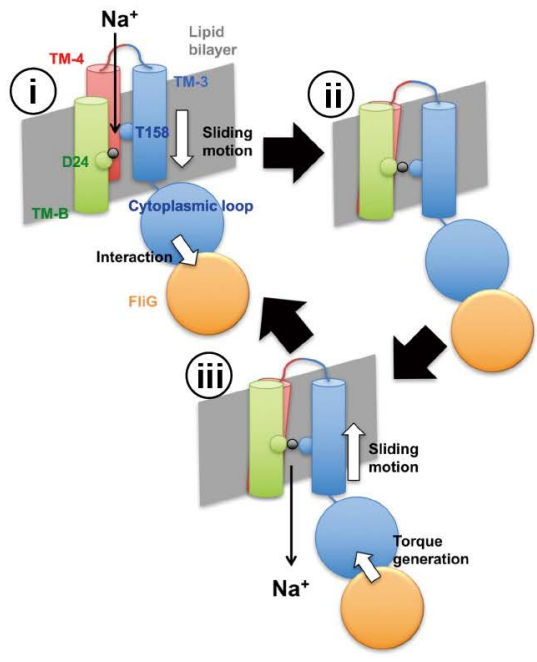

図 8. ビブリオ菌極べん毛固定子複合体の構造変換モデル (A) PomAB からなる固定子複合体のペリプラズム領域が，構 造変換をして，ペプチドグリカンあるいはT-リングと相互でき るように構造変換が起こる。(B) べん毛モータ一回転のメカノ ケミカル共役モデル。i） PomA の細胞質ループとC-リングの FliG-C 末端ドメインが相互作用することで，TM-3 抒よび TM-4 の細胞質側へのスライドを誘起する。ii）この動きで, PomAの 膜貫通へリックス 3（TM-3）の T158 が，PomB の膜貫通へリッ クス（TM-B）の D24 に向かって近づき, $\mathrm{Na}^{+}$結合部位を形成する。 iii) $\mathrm{Na}^{+}$が細胞質側に放出された後，TM-3 抢よびTM-4 は元の 位置に戻る。このスライド運動が, 細胞質ループの構造変化を引 き起こし, FliG との界面でトルクを生成する。尾上らの論文 (131) より引用した。
5:2のストイキオメトリーであることも示されている（14, 15)。ただし，Exb複合体については他のグループから $6: 3$ というモデルも出されている（94）。ExbB/ExbD に TonB が 結合して， $\mathrm{H}^{+}$駆動力を使って外膜での輸送を促進させる (121)。TonB の構造解析と蛍光偏光法による測定から, TonB がプロペラの様に回転して輸送を促進するといら機 構が考えられている $(16,54,56)$ 。もし，TonB の回転乇 デルが正しければ, MotBあるいはPomBが MotA や PomA の軸となって回転していることも十分に考えられ, 新しい回転モデルが提案されている $(17,25,143)$ 。

ビブリオ菌の固定子イオン認識部位の特定のため，大腸 菌やロドバクター菌 (Rhodobacter sphaeroides) の $\mathrm{H}^{+}$駆動 型べん毛モーターとビブリオ菌の $\mathrm{Na}^{+}$駆動型べん毛モ一 ターのキメラ実験が行われている $(2,4,36)$ 。その結果 からは，イオン認識部位の特定はできなかった。しかし， 大腸菌の MotB とビブリオ菌の PomB を膜貫通領域直後の プラグ領域で融合させた, ペリプラズム領域が大腸菌の MotB 由来になったキメラタンパク質（PotB）をPomA と ともに大腸菌の mot $A B$ 欠損株に導入すると運動能が回復 し， $\mathrm{Na}^{+}$駆動型モーターとして働くことが明らかにされた (5)。これは, $\mathrm{H}^{+}$駆動型の回転子タンパク質と $\mathrm{Na}^{+}$駆動型 の固定子タンパク質の間で相互作用できることを示して掠 り, 回転力発生機構のロバストネスを示している。分子系 統樹から真性細菌の起源に近いとされる超好熱菌Aquifex aeolicus の固定子 B サブユニットのペリプラズム領域を 大腸菌の MotB 由来にすれば, $\mathrm{Na}^{+}$駆動型モーターとして 働くことが分かり (161), 回転力発生機構のロバストネス の証明と, ベん毛の起源が $\mathrm{Na}^{+}$駆動型であることが提案 されている。イオン特異性については, グラム陽性菌のバ シラス属の菌で研究が進んでいる。グラム陽性菌の枯草菌 (Bacillus subtilis) は MotA/MotB と相同な固定子タンパク 質をもち， $\mathrm{H}^{+}$駆動力によって運動する $(97,111)$ 。好ア ルカリ性なバシラス属の菌の中には $\mathrm{Na}^{+}$駆動力を用いて 運動するものがあることが知られていた (41)。その菌か ら MotP/MotS と名付けられた $\mathrm{Na}^{+}$駆動固定子タンパク質 が同定され，枯草菌にも $\mathrm{H}^{+}$駆動型の MotA/MotB に加え て別個の固定子が存在することが明らかにされた (49)。 これを使ってサブュニットレベルでハイブリッドを作成し てみると, MotP/MotB は $\mathrm{H}^{+}$駆動型, MotA/MotS は $\mathrm{Na}^{+}$ 駆動型となることが示され，B サブュニットがイオン特異 性を決めていることが明らかにされた（50)。枯草菌の中 で，MotA/MoBの $\mathrm{Na}^{+}$駆動型モーターから，MotBの膜貫 通領域のイオンの入り口に対応する部分のアミノ酸変異の 導入によって， $\mathrm{H}^{+}$駆動型モーターに変更できることが明 らかにされた (163)。V. alginolyticus の PomA/PomB で，枯 草菌の変異を参考にして，変異を導入してみたが，イオン 特異性の変化するものは得られていない。

ビブリオ菌の固定子タンパク質 PomA と PomB に GFP を融合したタンパク質が作成され局在を可視化すること で，固定子複合体の極局在には，回転子構造を必要とする 
ことが示されていた (35)。固定子が動的に解離と集合を していることは推測されていたが，V. alginolyticus に沶い ては共役イオンであるナトリウムイオンの存在が, 固定子 のベん毛モーターに集合に必要であることが示された (34)。そこで我々は，PomA と PomB が膜内で複合体を作 り，この複合体がナトリウムイオンと結合することで回転 子との相互作用が可能な構造に変化し, べん毛回転子の周 りに集合して，モーターとして機能できるようになるとい らモデルを提案した。さらに，べん毛固定子がモーターの 周りに固定されるためには，PomA と回転子タンパク質 FliG の相互作用が必要であることが，べん毛形成するが モータ一機能を失った $f l i G$ の変異体を解析することで明 らかになった（70）。V. alginolyticus の極べん毛で提案され ているモーター構築のモデルを示す (図 9A)。

$\operatorname{mot} X$ と $\operatorname{mot} Y$ については，なぜこの遺伝子に変異が入 るとモータ一機能が損なわ和るかは疑問であった。この 2 つのモータータンパク質の生化学的性質を調べると, 膜夕 ンパク質ではなく、シグナル配列をもった外膜に存在する 分泌タンパク質であることが明らかにされた（127）。 MotX と MotY との直接的な相互作用が示され, さらに MotX と PomB との相互作用が示唆された (126)。MotX と MotY の性質が明らかになる中で，精製したべん毛の基 部体構造に，これら 2 つのタンパク質が含まれることが発 見された（164）。さらに，電子顕微鏡観察によって極べん 毛基部体の LP-リングの下にリング構造が発見され（Tリ ングと命名)，T-リングが MotX と MotY から構成されて いることが明らかにされた。T-リング構造に欠損があると, エネルギー変換ユニットである PomAB 複合体がべん毛 モーターの周りに集合できなくなることも示されて，モー タ一機能欠損の理由が判明した。MotY そついては結晶構 造解析が行われ，N末（MotY-N）とC末（MotY-C) の 2 つのドメインからなり，MotY-N は固定子の回転子周囲へ の集合に必要であり，MotY-C はペプチドグリカン層に結 合することで，固定子 - 回転子間相互作用を安定化してい ると推測された（71）。ビブリオ菌極べん毛の基部体にお いて，大腸菌やサルモネラ菌では見られないT-リングと いら構造がある他に，外膜に対応する LP-リングがやや大 きいといら特徵がある。基部体を精製してそこに含まれる タンパク質を分析すると，コレラ菌のベん毛形成と運動に 関与する $38 \mathrm{kDa}$ の flgT 遺伝子産物が含まれることが判明

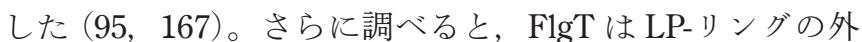
側に，H-リングと名付けた構造を作るために必要である こと, $\mathrm{FlgT}$ と MotY が直接的な相互作用があり， H-リン グがないと T-リングが形成されないことも明らかとなっ た。FlgT の結晶構造解析に成功し, FlgT が N, M, C と

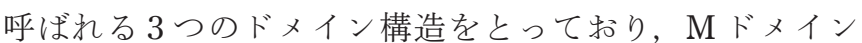
は MotY と, NM のドメインで他の H-リング構成タンパク 質と相互作用していることが示された (169)。クライオ電 子顕微鏡を用いた構造解析から, PomB のペリプラズム領 域と T-リング構造の相互作用モデルが提案されている
(A)

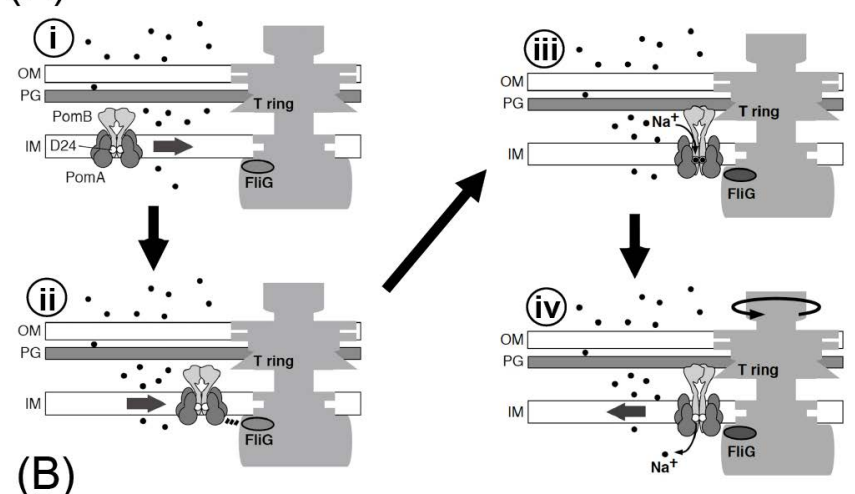

(B)

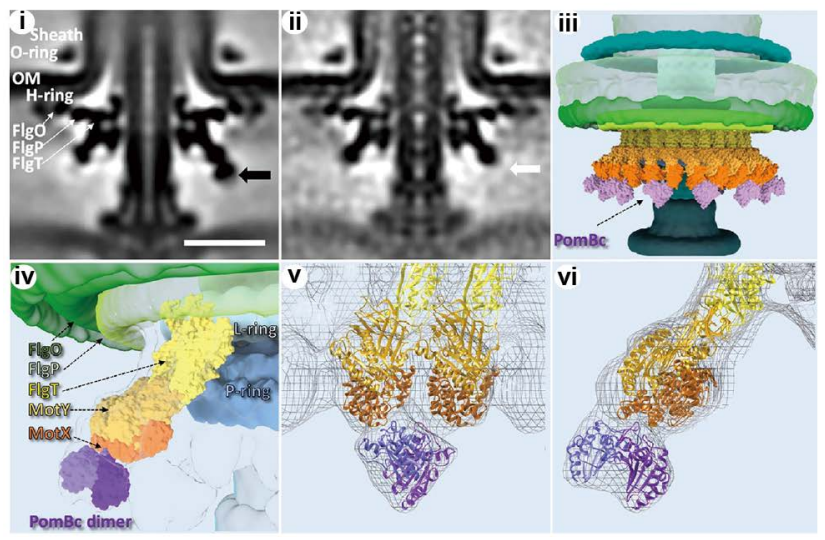

図 9. ビブリオ菌固定子活性化モデルと固定子の固定化機構 (A) PomA と PomB は固定子複合体を形成し, 膜上を拡散する (i)。 この複合体が極べん毛の基部体に遭遇すると，PomA は C-リン グを構成している FliG タンパク質のC 末端ドメインと相互作用 し (ii), この相互作用により固定子複合体に構造変化が引き起 こされ， $\mathrm{Na}^{+}$が固定子に流入できるようになる。PomB の Asp24 領域に $\mathrm{Na}^{+}$が結合することにより，大きな構造変化を PGB ドメ インに引き起こし，固定子が固定される（iii）。次に，結合した $\mathrm{Na}^{+}$が Asp24 領域から離れ，細胞質にリリースされることで卜ル クが生成される (iv)。 $\mathrm{Na}^{+}$が解離した固定子複合体は，回転子 から解離するが， $\mathrm{Na}^{+}$濃度が高い環境では，すぐに $\mathrm{Na}^{+}$が再結合 して,トルクを連続的に発生する。小嶋らの論文 (70) より引用 した。（B）ビブリオ菌特異的リング構造と固定子の固定化。（i） ビブリオ菌極ベん毛モーターの細胞膜上部のサブトモグラム平均 構造の $2 \mathrm{D}$ スライス像。H-リング構成タンパク質の $\mathrm{FlgO}, \mathrm{FlgP}$, 特よび FlgT が白抜きの文字で標識されている。黒い矢印は，Tリングの下の特徵的な密度を示している。(ii) $p o m A B$ 欠損菌の 極べん毛モータ一の細胞膜上部のサブトモグラム平均構造の 2D スライス像。白い矢印で示される領域は，（i）で見られたT-リ ングの下部の密度の損失を示している。(iii) PomB ペリプラズム 部分の結晶構造を，T-リングの下部の密度に紫色でクライオ ET 密度に適合させた。（iv）拡大図は，PG 結合部位を介して直接相 互作用するダイマーの PomB ペリプラズム領域と，T-リングの 下部にある MotXを適合させている。（v, vi）クライオ ET 密度マッ プ (メッシュ) と, FlgT, MotY, MotX 扎よびPomB の原子モデ ルのリボン構造を重站わせ表示した。Zhuらの論文（188）よ り引用した。

（188）（図 9B）。面白いことに，B サブュニットのペリプ ラズム領域を大腸菌の MotB 由来にしたキメラタンパク質 PotBでは，T-リングが欠損しても，固定子として機能す ることが示されている(118)。

\section{8. 細菌ベん毛モーター回転子}

回転子中の C-リングは，MS-リング側から FliG，FliM， FliNがそれぞれ 34，34，102 分子でリングを構築すると 
考兄られている（13）。先にも述べたようにC-リングは, 固定子と相互作用して回転力発生に関わるだけでなく，回 転方向の制御にも重要である。回転方向制御が異常になる 変異株の取得を目的として, ランダム変異導入で得られた V. alginolyticus を解析すると, 方向制御が異常になる变異 の多くが fliG, fliM に生じていた。FliG は, N 末端側から $\mathrm{N}$-terminal $\left(\mathrm{FliG}_{\mathrm{N}}\right)$, Middle $\left(\mathrm{FliG}_{\mathrm{M}}\right), \mathrm{C}$-terminal $\left(\mathrm{FliG}_{\mathrm{C}}\right)$ の 3 つのドメインに分けられ, 構造解析が行われ, 好熱菌 の Thermotoga maritima 由来の $\mathrm{FliG}_{\mathrm{C}}$ と $\mathrm{FliG}_{\mathrm{M}}$ の結晶構造 が報告されている (11，89）。また，超好熱菌Aquifex aeolicus では全長 FliG の構造が解かれている(84)。残念ながら, 部分構造を含め, ビブリオ菌と大腸菌・サルモネラ菌の FliG の構造は解けていない。それぞれのドメインには, $\beta$-catenin 等に見られるタンパク質間相互作用に重要な Armadillo repeat motif (ARM) が存在する (46)。ARM は イソロイシン，ロイシン，バリンなぞの疎水性側鎖が, $\alpha$-helix 上で同一の向きを向いている繰り返し配列である。 V. alginolyticus の FliG は351アミノ酸からなる分子量 $38.6 \mathrm{kDa}$ のタンパク質であり, $\mathrm{FliG}_{\mathrm{N}}, \mathrm{FliG}_{\mathrm{M}}, \mathrm{FliG}_{\mathrm{c}}$ には それぞれ 20-127，133-202，235-343 番目のアミノ酸が含 まれる。FliFの $\mathrm{C}$ 末端アミノ酸残基と FliG と相互作用が 直接的に検出されている $(122) 。 \mathrm{FliG}_{\mathrm{c}}$ は固定子の細胞質 領域と相互作用寸ることでモーターの回転力の発生に関与 する。この相互作用には, 荷電残基の寄与が重要であるこ とが遺伝学的にわかって扮り, 少なくともV. alginolyticus の FliG-K284，D301，D308，D309 残基が PomA と相互作 用することが示唆されている (159)。FliG に扮いて FliM と相互作用することが示されている EHPQR-motif（E144，H145，P146，Q147，R179 残基）と 呼ばれる保存性の非常に高い領域が存在する。

FliM は FliG 及び FliN と相互作用するだけでなく, 走化 性因子である CheY と相互作用する (85，105)。CheY は FliN とも相互作用する (145)。FliM, FliN が CheY と相互 作用することで，べん毛の回転方向が制御される（177）。 CheYを介した FliM の構造変化は, FliG に伝わり, FliG とPomA の相互作用界面を変化させることで回転方向を変 化させると考光られている。具体的には FliM の構造変化 が $\mathrm{FliG}_{\mathrm{M}}, \mathrm{FliG}_{\mathrm{C}}$ に存在する $\mathrm{ARM}_{\mathrm{M}}$ 及び, $\mathrm{ARM}_{\mathrm{C}}$ の $\mathrm{FliG}$ 分 子内/分子間相互作用を変化させることで FliG の構造変 化を引き起こす $(9,63,107)$ 。時計回りでは, $\mathrm{ARM}_{\mathrm{M}}$ と $\mathrm{ARM}_{\mathrm{C}}$ が分子内で相互作用することにより FliG がコンパ クトな構造を取り, 反時計回りでは, $\mathrm{ARM}_{\mathrm{M}}$ と $\mathrm{ARM}_{\mathrm{C}}$ が リング上で隣り合う FliG と分子間相互作用することによ り, FliG が伸びた構造を取ると考兄られている。この分 子内/分子間相互作用は $\mathrm{FliG}_{\mathrm{M}}$ に存在する helix $\mathrm{MC}_{\mathrm{MC}}$ と呼ば 孔る $\alpha$-helix の構造変化によって制御され，時計回りの状 態では helix $\mathrm{MC}_{\mathrm{MC}}$ が注どけると考兄られている。回転方向に 異常がみられる FliG 変異が大腸菌やサルモネラ菌で解析 されて赦り, それらの変異は, EHPQR-motif, helix $\mathrm{FliG}_{\mathrm{M}}$ と FliG $\mathrm{C}$ をつなぐリンカー, $\mathrm{ARM}_{\mathrm{C}}$ ，に存在する。V. alginolyticus の FliG 変異も同様な結果が生じていることか ら同じような構造変化が起こっていると推測されている。 我々は核磁気共鳴法やクライオ電子顕微鏡を用いて, 回転 方向制御メカニズムの解明着手しているが（図 10）（13, 117), 回転方向切り替光の際に生じる具体的な FliG の構 造変化と, 時計回りと反時計回りでトルクを生み出す分子 機構はわかっていない。

CheY が C-リングの内側か外側のぞちらかに結合するか は議論がなされていた。米国 Yale 大学 Liu 博士との共同 研究で, 回転方向が時計回りに固定されるV. alginolyticus の変異体をクライオ電顕で観察すると FliM の外側に CheY の密度がうっすらと見えていた（13）。そして，Liuらのグ ループがペリプラズムにベん毛をもつボレリア菌 (Borrelia burgdorferi) で CheY がリングの外側から FliM に結合して いることを見出した（17）。しかしながら，C-リング中の FliM に対して, CheY は忌避シグナルによってリン酸化を らけてC-リングに結合できるようになるが，リン酸化さ れた CheY (CheY-P) がどれだけ結合すると回転方向が時 計回りになるのかはわかっていない。FliGの ARM がリン グ中の隣の FliG 分子の構造変化に影響を与兄ることから,

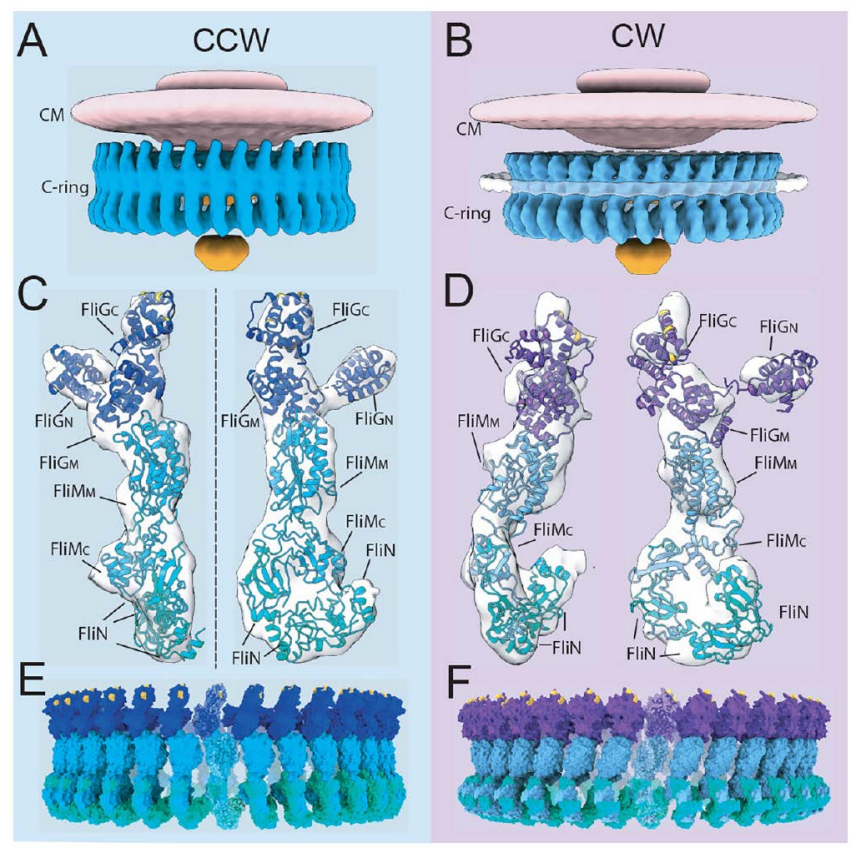

図 10. 反時計回転 $(\mathrm{CCW})$ 预よび時計回転 (CW) のCリング のモデル

$\mathrm{CCW} モ ー タ ー （ \mathrm{~A} ）$ 扎よび CW モーター（B）のクライオ電子顕 微鏡トモグラフィーで得られたベん毛モーターC-リング部分の $3 \mathrm{D}$ サーフェスレンダリング。 MS リングと細胞質膜 (CM) はピ ンク色, C- リングは青色, TypeIII 輸送装置はオレンジ色で示し た。(C) クライオ電子顕微鏡で得られた CCW のC-リング構造 密度（灰色）に, FliG, FliM, FliN からなるC-リングの 1 つのユ ニットをあてはめた。ユニットを 2 つの異なる方向から見た図を 示した。FliG は青, FliM は水色, FliN は緑で示す。(D) クライ 才電子顕微鏡で得ら水た CW の C- リング構造密度（灰色）に, FliG, FliM, FliN からなるC-リングの 1 つのユニットをあてはめ た。ユニットを $2 つ の$ 異なる方向から見た図を示した。FliG は紫, FliM は水色，FliN は緑でしめす。（E）C-リングのユニットを 34 回転対称にあてはめて CCW 構造（E）と CW 構造（F）をモデル 化した。Carroll らの論文（13）より引用した。 
CheY の結合は FliM に対してアロステリックに働き，そ れに応答した FliG の構造変化がリング全体に広がること で，すべての FliM に CheY-Pが結合していなくてもC-リ ング全体が大きく構造変化すると予想している。

\section{9. ベん毛モーターの走化性応答}

先にも述べたように回転方向の制御は，走化性シグナル (Che）が C-リングに伝わることによって行われる。走化 性は，細胞がべん毛を回転させて移動することにより变化 した細胞周囲の環境変化を，走化性受容体が認識しべん毛 モーターの回転方向を変化させるシグナル応答である （98，175）（図 11）。大腸菌では，細胞膜上の Tsr あるい は Tar，ビブリオ菌では Mlp24 あるいは Mlp37 などと呼ば 孔る走化性受容体 (MCPs: methyl-accepting chemotaxis proteins）に，糖やアミノ酸などの誘引物質や Phenol や一 部のアミノ酸等の忌避物質が結合することでシグナル伝達 が開始される。発生したシグナルは，Che 因子のリン酸化/ 脱リン酸化を介したリン酸基の転移を介して，C-リングの 構造を変化させる。具体的には, CheW, CheA, CheY の順 にリン酸基が伝達され，リン酸化を受けた CheY（CheY-P） が FliM に結合することで回転方向を反時計回りから時計 回りに切り替える。同じくChe 因子であるCheZ は CheY-Pの脱リン酸化を促進する働きがあり, CheYが FliM から外れると回転方向が反時計回りに戻る。つまり, 細胞質中の CheY と CheY-P の濃度の比が, 回転方向を決 めるのに重要で，細胞周囲に誘引物質が多いとまっすぐ泳 ぐ反時計方向に回転するが，忌避物質が多いと回転方向を 切り替えて（大腸菌ではタンブルとも呼ばれる）時計回り

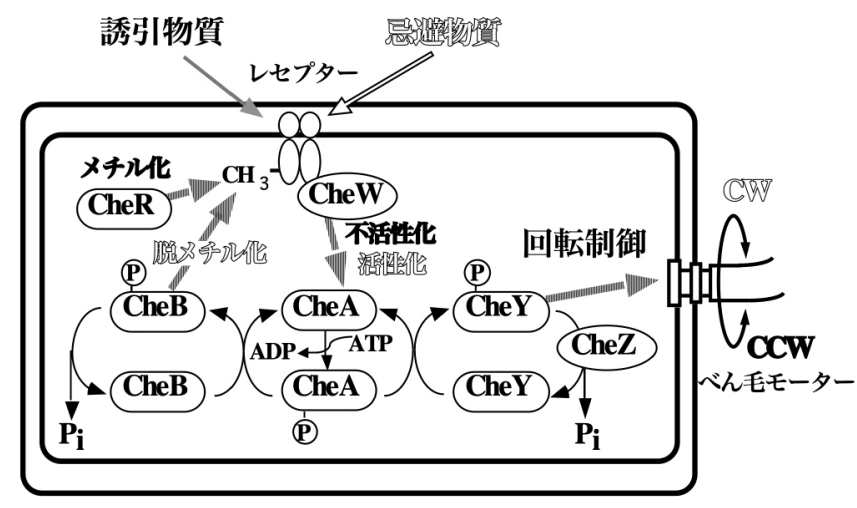

図 11．細菌の走化性シグナル伝達経路

大腸菌の走化性シグナル伝達経路を示す。細胞膜状上の走化性 レセプターが忌避物質（repellent）を認識すると, CheAの自己 リン酸化が促進され，リン酸基が CheY に転移される。リン酸化 型 CheY はべん毛モーターのスイッチに結合し, べん毛の回転方 向を時計方向 $(\mathrm{CW})$ に逆転させる。その結果, 菌はタンブルし, 遊泳方向を変える。CheY は自己脱りン酸化あるいは CheZ によっ て脱リン酸化されモーターから解離する。一方, 誘引物質を認識 すると, CheAの自己リン酸化は抑制され，結果的に菌は滑らか な遊泳を続ける。レセプターは，CheRによってメチル化， CheB によって脱メチル化される。メチル化されたレセプターは誘引物 質を認識しにくくなり CheA 活性の抑制が低下し, 結果的にタン ブルする確率が上昇する。ダイマーのレセプターがさらに 3 集 まって，集合体となりそこに CheW と CheA が結合した状態でシ グナル伝達する。
回転が優位になる。反時計回りと時計回りを組み合わせる ことにより，細胞は自身の生存に有利な環境にとどまるこ とができる。この基本的な走化性のシステムは細菌に共通 である。

興味深いことにビブリオ菌では，側べん毛は，忌避シグ ナルによるCheY-P の増加によってモーターが止まり，極 ベん毛は，忌避シグナルにより時計回りでタンブルするの ではなく，時計回りと反時計回りの切り替えが増加し，そ の場を行ったり来たりする遊泳を示す $(45,66)$ 。極べん 毛では，べん毛を先にして泳ぐとべん毛同士がからまって しまらことになる。この極べん毛の回転方向切り替兄頻度 が増加した変異が，FliG に E144D として見つかっている （117）。この残基はC-リング構造において FliM との境界 面にある。大腸菌の CheY-P に比べてビブリオ菌の CheY-P が FliM から速く解離することにより，大腸菌と異なる応 答を行なっているのではないかと考光られている。もら一 点ビブリオ菌での走化性に打いて大腸菌とは異なる特徵と して，走化性受容体様蛋白質が多いことが挙げられる。V. cholerae では 40 個以上の走化性レセプタ一様遺伝子 (MLP) を持っていると推定されている（12，39）。V. cholerae の 3 セットの che 遺伝子クラスターのらち, 他のVibrio の che 遺伝子との相同性が高いのはクラスターII の遺伝子であ る。3つの che 遺伝子クラスターの走化性への関与は, cheA の機能解析によって調べられた（37）。そこで，走化 性シグナル伝達系の出力を担う CheY に着目して解析した ところ，べん毛の逆回転を引き起こしたのは，クラスター II の CheY3 のみであった（47）。やはり走化性に関与する のはクラスターII だけであり，クラスターI と III は走化 性以外の生理機能への関与が予想されている。一方，V. alginolyticus やV. parahaemolyticus は，極べん毛と側べん毛 という 2 種類のべん毛をもつが, 2 つのべん毛系に执いて, 走化性は移動に必要である (144)。二つのべん毛が一つの che 遺伝子群によって制御されていることが示されている （66）。また，クラスターIのシステムは，細胞エネルギー 状態の低下に応答して, 細胞の状態をコントロールするた めに使われるのではないかと推測されている $(40)$ 。ビブ リ才菌では，大腸菌よりも多くの走化性レセプターをもっ ているが，構造も大腸菌の Tsr や Tar とは少し異なること が分かっている。大腸菌では 4HB（four-helix bundle）ド メインと呼ばれる細胞外領域をもつレセプターを持つのに 対して，ビブリオ菌では Cache（動物の voltage-gated $\mathrm{Ca}^{2+}$ channel と細菌の chemoreceptor からとった名前）ドメイ ンと呼ばれる細胞外タンパク質領域をもつレセプターを 持っている $(96,132,174)$ 。V c cholerae の走化性様レセプター の Mlp7，Mlp8，Mlp24 と Mlp30 が病原性に関わっている ことが示されている (18，119)。Mlp24 に相同性をもつタウ リンとセリンに走化性応答を引き起こす主要な V. cholerae のレセプターである Mlp37 の細胞外領域の構造が決定さ れている $(120 ， 157)$ 。Mlp24 の細胞外領域の構造も決定 され， $\mathrm{Ca}^{2+}$ とよってリガンドの親和性が大きく変化する 
ことも示されている（158）。ビブリオ菌が多くの走化性様 レセプターをもつことは，多様な環境に対応するためだと 考光られている。それらレセプターが生存にどのよらに必 要であるかについては, 今後の研究を待つ必要がある。

\section{おわりに}

我々はV. alginolyticus の極べん毛の研究を長年やってき た。ヒトに病原性を示す腸炎ビブリオ菌 V. parahaemolyticus とは，同じ菌であると言っても過言ではなく，べん毛に関 しては, そのまま腸炎ビブリオ菌にあてはめて議論できる。 また，極べん毛に関しては，V. choleraeのべん毛とほぼ同 じである。機能的な観点からでは, 大腸菌のべん毛の固定 子をビブリオのナトリウム型の固定子と入れ替えても, 大 腸菌でも機能する。さらには, 超高熱菌 Aquifexの固定子 タンパク質を入れ替えても機能することが示されている。 これは，種間に拈いて機能的に重要な構造は保持される良 い例ではないだろらか。本総説の筆者の一人である本間は, 今年度で大学を退職する。細菌のべん毛モーター研究のさ らなる発展を祈りたい。

\section{謝辞}

名古屋大学理学部分子生物学科の分子第 4 講座から, 今 は, 大学院理学研究科生命理学専攻生体膜機能グループと 名前は変わったが, 多くの共同研究者や学生がべん毛研究 に携わってくれた。この総説にも引用した多くの成果を支 㝋てくれた。そして, 名古屋大学の素晴らしい研究環境と 共同研究者に感謝したい。また, 細菌の電子顕微鏡写真は, 名古屋大学技術職員の牧貴美香博士に撮っていただいた。

本稿内容について，開示すべきCOI 関係にある企業な ぞはありません。

\section{文献}

1) Allen, R.D., Baumann, P. (1971): Structure and arrangement of flagella in species of the genus Beneckea and Photobacterium fischeri. J. Bacteriol. 107, 295-302.

2) Asai, Y., Kawagishi, I., Sockett, E., Homma, M. (1999): Hybrid motor with the $\mathrm{H}^{+}$-and $\mathrm{Na}^{+}$-driven components can rotate Vibrio polar flagella by using sodium ions. J. Bacteriol. 181, 6322-6338.

3) Asai, Y., Kojima, S., Kato, H., Nishioka, N., Kawagishi, I., Homma, M. (1997): Putative channel components for the fast-rotating sodium-driven flagellar motor of a marine bacterium. J. Bacteriol. 179, 5104-5110.

4) Asai, Y., Sockett, R.E., Kawagishi, I., Homma, M. (2000): Coupling ion specificity of chimeras between $\mathrm{H}^{+}-$and $\mathrm{Na}^{+}$-driven motor proteins, MotB and PomB, in Vibrio polar flagella. EMBO J. 19, 3639-3648.

5) Asai, Y., Yakushi, T., Kawagishi, I., Homma, M. (2003): Ion-coupling determinants of $\mathrm{Na}^{+}$-driven and $\mathrm{H}^{+}$-driven flagellar motors. J. Mol. Biol. 327, 453-463.

6) Atsumi, T., Maekawa, Y., Yamada, T., Kawagishi, I., Imae, Y., Homma, M. (1996): Effect of viscosity on swimming by the lateral and polar flagella of Vibrio alginolyticus. J. Bacteriol. 178,
5024-5026.

7) Atsumi, T., Mccarter, L., Imae, Y. (1992): Polar and lateral flagellar motors of marine Vibrio are driven by different ion-motive forces. Nature 355, 182-184.

8) Austin, B. (2010): Vibrios as causal agents of zoonoses. Vet. Microbiol. 140, 310-317.

9) Baker, M.A., Hynson, R.M., Ganuelas, L.A., Mohammadi, N.S., Liew, C.W., Rey, A.A., Duff, A.P., Whitten, A.E., Jeffries, C.M., Delalez, N.J., Morimoto, Y.V., Stock, D., Armitage, J.P., Turberfield, A.J., Namba, K., Berry, R.M., Lee, L.K. (2016): Domain-swap polymerization drives the self-assembly of the bacterial flagellar motor. Nat. Strct. Mol. Biol. 23, 197-203.

10) Baumann, P., Baumann, L. (1977): Biology of the marine enterobacteria: genera Beneckea and Photobacterium. Annu. Rev. Microbiol. 31, 39-61.

11) Brown, P.N., Hill, C.P., Blair, D.F. (2002): Crystal structure of the middle and $\mathrm{C}$-terminal domains of the flagellar rotor protein FliG. EMBO J. 21, 3225-3234.

12) Butler, S.M., Camilli, A. (2005): Going against the grain: chemotaxis and infection in Vibrio cholerae. Nat. Rev. Microbiol. 3, 611-620.

13) Carroll, B.L., Nishikino, T., Guo, W., Zhu, S., Kojima, S., Homma, M., Liu, J. (2020): The flagellar motor of Vibrio alginolyticus undergoes major structural remodeling during rotational switching. eLife 9, e61446.

14) Celia, H., Botos, I., Ni, X., Fox, T., De Val, N., Lloubes, R., Jiang, J., Buchanan, S.K. (2019): Cryo-EM structure of the bacterial Ton motor subcomplex ExbB-ExbD provides information on structure and stoichiometry. Commun. Biol. 2, 358.

15) Celia, H., Noinaj, N., Zakharov, S.D., Bordignon, E., Botos, I., Santamaria, M., Barnard, T.J., Cramer, W.A., Lloubes, R., Buchanan, S.K. (2016): Structural insight into the role of the Ton complex in energy transduction. Nature 538, 60-65.

16) Chang, C., Mooser, A., Pluckthun, A., Wlodawer, A. (2001): Crystal structure of the dimeric C-terminal domain of TonB reveals a novel fold. J. Biol. Chem. 276, 27535-27540.

17) Chang, Y., Zhang, K., Carroll, B.L., Zhao, X., Charon, N.W., Norris, S.J., Motaleb, M., Li, C., Liu, J. (2020): Molecular mechanism for rotational switching of the bacterial flagellar motor. Nat. Struct. Mol. Biol. doi: 10.1038/s41594-020-0497-2

18) Chaparro, A.P., Ali, S.K., Klose, K.E. (2010): The ToxT-dependent methyl-accepting chemoreceptors AcfB and TcpI contribute to Vibrio cholerae intestinal colonization. FEMS Microbiol. Lett. 302, 99-105.

19) Chernyak, B.V., Dibrov, P.A., Glagolev, A.N., Sherman, M.Y., Skulachev, V.P. (1983): A novel type of energetics in a marine aklali-tolerant bacterium: $\mathrm{Na}^{+}$-driven motility and sodium cycle. FEBS Lett. 164, 38-42.

20) Chu, J., Liu, J., Hoover, T.R. (2020): Phylogenetic distribution, ultrastructure, and function of bacterial flagellar sheaths. Biomolecules 10, 363.

21) Correa, N.E., Lauriano, C.M., Mcgee, R., Klose, K.E. (2000): Phosphorylation of the flagellar regulatory protein $\mathrm{FlrC}$ is necessary for Vibrio cholerae motility and enhanced colonization. Mol. Microbiol. 35, 743-755.

22) Correa, N.E., Peng, F., Klose, K.E. (2005): Roles of the regulatory proteins FlhF and FlhG in the Vibrio cholerae flagellar transcription hierarchy. J. Bacteriol. 187, 6324-6332.

23) Dasgupta, N., Arora, S.K., Ramphal, R. (2000): fleN, a gene that regulates flagellar number in Pseudomonas aeruginosa. J. Bacteriol. 182, 357-364.

24) Dean, G.D., Macnab, R.M., Stader, J., Matsumura, P., Burks, C. (1984): Gene sequence and predicted amino acid sequence of 
the motA protein, a membrane-associated protein required for flagellar rotation in Escherichia coli. J. Bacteriol. 159, 991-999.

25) Deme, J.C., Johnson, S., Vickery, O., Muellbauer, A., Monkhouse, H., Griffiths, T., James, R.H., Berks, B.C., Coulton, J.W., Stansfeld, P.J., Lea, S.M. (2020): Structures of the stator complex that drives rotation of the bacterial flagellum. Nat. Microbiol. 5, 1553-1564.

26) Deng, W., Marshall, N.C., Rowland, J.L., Mccoy, J.M., Worrall, L.J., Santos, A.S., Strynadka, N.C.J., Finlay, B.B. (2017): Assembly, structure, function and regulation of type III secretion systems. Nat. Rev. Microbiol. 15, 323-337.

27) diCenzo, G.C., Finan, T.M. (2017): The divided bacterial genome: structure, function, and evolution. Microbiol. Mol. Biol. Rev. 81, e00019-17

28) Echazarreta, M.A., Klose, K.E. (2019): Vibrio flagellar synthesis. Front. Cell Infect. Microbiol. 9, 131.

29) Egan, E.S., Waldor, M.K. (2003): Distinct replication requirements for the two Vibrio cholerae chromosomes. Cell 114, 521-530.

30) Evans, L.D., Stafford, G.P., Ahmed, S., Fraser, G.M., Hughes, C. (2006): An escort mechanism for cycling of export chaperones during flagellum assembly. Proc. Natl. Acad. Sci. U.S.A. 103, 17474-17479.

31) Ferreira, J.L., Gao, F.Z., Rossmann, F.M., Nans, A., Brenzinger, S., Hosseini, R., Wilson, A., Briegel, A., Thormann, K.M., Rosenthal, P.B., Beeby, M. (2019) : gamma-proteobacteria eject their polar flagella under nutrient depletion, retaining flagellar motor relic structures. PLoS Biol. 17, e3000165.

32) Francis, N.R., Sosinsky, G.E., Thomas, D., Derosier, D.J. (1994): Isolation, characterization and structure of bacterial flagellar motors containing the switch complex. J. Mol. Biol. 235, 1261-1270.

33) Fraser, G.M., Bennett, J.C., Hughes, C. (1999): Substratespecific binding of hook-associated proteins by FlgN and FliT, putative chaperones for flagellum assembly. Mol. Microbiol. 32, 569-580.

34) Fukuoka, H., Wada, T., Kojima, S., Ishijima, A., Homma, M. (2009): Sodium-dependent dynamic assembly of membrane complexes in sodium-driven flagellar motors. Mol. Microbiol. 71, 825-835.

35) Fukuoka, H., Yakushi, T., Kusumoto, A., Homma, M. (2005): Assembly of motor proteins, PomA and PomB, in the $\mathrm{Na}^{+}$-driven stator of the flagellar motor. J. Mol. Biol. 351, 707-717.

36) Gosink, K.K., Häse, C.C. (2000): Requirements for conversion of the $\mathrm{Na}^{+}$-driven flagellar motor of Vibrio cholerae to the $\mathrm{H}^{+}$-driven motor of Escherichia coli. J. Bacteriol. 182, 4234-4240

37) Gosink, K.K., Kobayashi, R., Kawagishi, I., Häse, C.C. (2002): Analyses of the roles of the three cheA homologs in chemotaxis of Vibrio cholerae. J. Bacteriol. 184, 1767-1771.

38) Green, J.C., Kahramanoglou, C., Rahman, A., Pender, A.M., Charbonnel, N., Fraser, G.M. (2009): Recruitment of the earliest component of the bacterial flagellum to the old cell division pole by a membrane-associated signal recognition particle family GTP-binding protein. J. Mol. Biol. 391, 679-690.

39) Heidelberg, J.F., Eisen, J.A., Nelson, W.C., Clayton, R.A., Gwinn, M.L., Dodson, R.J., Haft, D.H., Hickey, E.K., Peterson, J.D., Umayam, L., Gill, S.R., Nelson, K.E., Read, T.D., Tettelin, H., Richardson, D., Ermolaeva, M.D., Vamathevan, J., Bass, S., Qin, H., Dragoi, I., Sellers, P., Mcdonald, L., Utterback, T., Fleishmann, R.D., Nierman, W.C., White, O. (2000): DNA sequence of both chromosomes of the cholera pathogen Vibrio cholerae. Nature 406, 477-483.
40) Hiremath, G., Hyakutake, A., Yamamoto, K., Ebisawa, T., Nakamura, T., Nishiyama, S., Homma, M., Kawagishi, I. (2015): Hypoxia-induced localization of chemotaxis-related signaling proteins in Vibrio cholerae. Mol. Microbiol. 95, 780-790.

41) Hirota, N., Imae, Y. (1983): $\mathrm{Na}^{+}$-driven flagellar motors of an alkalophilic Bacillus strain YN-1. J. Biol. Chem. 258, 1057710580 .

42) Homma, M., Aizawa, S.-I., Dean, G.E., Macnab, R.M. (1987): Identification of the M-ring protein of the flagellar motor of Salmonella typhimurium. Proc. Natl. Acad. Sci. U.S.A. 84, 7483-7487.

43) Homma, M., Iino, T., Kutsukake, K., Yamaguchi, S. (1986): In vitro reconstitution of flagellar filaments onto hooks of filamentless mutants of Salmonella typhimurium by addition of hook-associated proteins. Proc. Natl. Acad. Sci. U.S.A. 83, 6169-6173.

44) Homma, M., Kutsukake, K., Iino, T., Yamaguchi, S. (1984): Hook-associated proteins essential for flagellar filament formation in Salmonella typhimurium. J. Bacteriol. 157, 100-108.

45) Homma, M., Oota, H., Kojima, S., Kawagishi, I., Imae, Y. (1996): Chemotactic responses to an attractant and a repellent in the flagellar systems of Vibrio alginolyticus. Microbiology 142, 2777-2783.

46) Huber, A.H., Nelson, W.J., Weis, W.I. (1997): Three-dimensional structure of the armadillo repeat region of beta-catenin. Cell 90, 871-882.

47) Hyakutake, A., Homma, M., Austin, M.J., Boin, M.A., Hase, C.C., Kawagishi, I. (2005): Only one of the five CheY homologs in Vibrio cholerae directly switches flagellar rotation. J. Bacteriol. 187, 8403-8410.

48) Inaba, S., Nishigaki, T., Takekawa, N., Kojima, S., Homma, M. (2017): Localization and domain characterization of the SflA regulator of flagellar formation in Vibrio alginolyticus. Genes Cells 22, 619-627.

49) Ito, M., Hicks, D.B., Henkin, T.M., Guffanti, A.A., Powers, B.D., Zvi, L., Uematsu, K., Krulwich, T.A. (2004): MotPS is the stator-force generator for motility of alkaliphilic Bacillus, and its homologue is a second functional Mot in Bacillus subtilis. Mol. Microbiol. 53, 1035-1049.

50) Ito, M., Terahara, N., Fujinami, S., Krulwich, T.A. (2005): Properties of motility in Bacillus subtilis powered by the $\mathrm{H}+$-coupled MotAB flagellar stator, $\mathrm{Na}^{+}$-coupled MotPS or hybrid stators MotAS or MotPB. J. Mol. Biol. 352, 396-408.

51) Jaques, S., Kim, Y.K., Mccarter, L.L. (1999): Mutations conferring resistance to phenamil and amiloride, inhibitors of sodium-driven motility of Vibrio parahaemolyticus. Proc. Natl. Acad. Sci. U.S.A. 96, 5740-5745.

52) Jha, J.K., Demarre, G., Venkova-Canova, T., Chattoraj, D.K. (2012): Replication regulation of Vibrio cholerae chromosome II involves initiator binding to the origin both as monomer and as dimer. Nucleic Acids Res. 40, 6026-6038.

53) Johnson, S., Fong, Y.H., Deme, J.C., Furlong, E.J., Kuhlen, L., Lea, S.M. (2020): Symmetry mismatch in the MS-ring of the bacterial flagellar rotor explains the structural coordination of secretion and rotation. Nat. Microbiol. 5, 966-975.

54) Jordan, L.D., Zhou, Y., Smallwood, C.R., Lill, Y., Ritchie, K., Yip, W.T., Newton, S.M., Klebba, P.E. (2013): Energy-dependent motion of TonB in the Gram-negative bacterial inner membrane. Proc. Natl. Acad. Sci. U.S.A. 110, 11553-11558.

55) Karlinsey, J.E., Lonner, J., Brown, K.L., Hughes, K.T. (2000): Translation/secretion coupling by type III secretion systems. Cell, 102, 487-497.

56) Kaserer, W.A., Jiang, X., Xiao, Q., Scott, D.C., Bauler, M., 
Copeland, D., Newton, S.M., Klebba, P.E. (2008): Insight from TonB hybrid proteins into the mechanism of iron transport through the outer membrane. J. Bacteriol. 190, 4001-4016.

57) Kawagishi, I., Imagawa, M., Imae, Y., Mccarter, L., Homma, M. (1996): The sodium-driven polar flagellar motor of marine Vibrio as the mechanosensor that regulates lateral flagellar expression. Mol. Microbiol. 20, 693-699.

58) Kawagishi, I., Maekawa, Y., Atsumi, T., Homma, M., Imae, Y. (1995): Isolation of the polar and lateral flagellum-defective mutants in Vibrio alginolyticus and identification of their flagellar driving energy sources. J. Bacteriol. 177, 5158-5160.

59) Kawagishi, I., Nakada, M., Nishioka, N., Homma, M. (1997): Cloning of a Vibrio alginolyticus $r p o N$ gene that is required for polar flagellar formation. J. Bacteriol. 179, 6851-6854.

60) Keyhani, N.O., Roseman, S. (1999): Physiological aspects of chitin catabolism in marine bacteria. Biochim. Biophys. Acta 1473, 108-122.

61) Khanra, N., Rossi, P., Economou, A., Kalodimos, C.G. (2016): Recognition and targeting mechanisms by chaperones in flagellum assembly and operation. Proc. Natl. Acad. Sci. U.S.A. 113, 9798-9803.

62) Kim, Y.K., Mccarter, L.L. (2000): Analysis of the polar flagellar gene system of Vibrio parahaemolyticus. J. Bacteriol. 182, 3693-3704.

63) Kinoshita, M., Furukawa, Y., Uchiyama, S., Imada, K., Namba, K., Minamino, T. (2018): Insight into adaptive remodeling of the rotor ring complex of the bacterial flagellar motor. Biochem. Biophy. Res. Comm. 496, 12-17.

64) Kitaoka, M., Nishigaki, T., Ihara, K., Nishioka, N., Kojima, S., Homma, M. (2013): A novel dnaJ family gene, sflA, encodes an inhibitor of flagellation in marine Vibrio species. J. Bacteriol. 195, 816-822.

65) Klose, K.E., Mekalanos, J.J. (1998): Differential regulation of multiple flagellins in Vibrio cholerae. J. Bacteriol. 180, 303-316.

66) Kojima, M., Kubo, R., Yakushi, T., Homma, M., Kawagishi, I. (2007): The bidirectional polar and unidirectional lateral flagellar motors of Vibrio alginolyticus are controlled by a single CheY species. Mol Microbiol, 64, 57-67.

67) Kojima, M., Nishioka, N., Kusumoto, A., Yagasaki, J., Fukuda, T., Homma, M. (2011): Conversion of mono-polar to peritrichous flagellation in Vibrio alginolyticus. Microbiol. Immunol. 55, 76-83.

68) Kojima, S., Imada, K., Sakuma, M., Sudo, Y., Kojima, C., Minamino, T., Homma, M., Namba, K. (2009): Stator assembly and activation mechanism of the flagellar motor by the periplasmic region of MotB. Mol. Microbiol. 73, 710-718.

69) Kojima, S., Imura, Y., Hirata, H., Homma, M. (2020): Characterization of the MinD/ParA-type ATPase FlhG in Vibrio alginolyticus and implications for function of its monomeric form. Genes Cells 25, 279-287.

70) Kojima, S., Nonoyama, N., Takekawa, N., Fukuoka, H., Homma, M. (2011): Mutations targeting the C-terminal domain of FliG can disrupt motor assembly in the $\mathrm{Na}^{+}$-driven flagella of Vibrio alginolyticus. J. Mol. Biol. 414, 62-74.

71) Kojima, S., Shinohara, A., Terashima, H., Yakushi, T., Sakuma, M., Homma, M., Namba, K., Imada, K. (2008): Insights into the stator assembly of the Vibrio flagellar motor from the crystal structure of MotY. Proc. Natl. Acad. Sci. U.S.A. 105, 7696-7701.

72) Kojima, S., Takao, M., Almira, G., Kawahara, I., Sakuma, M., Homma, M., Kojima, C., Imada, K. (2018): The helix rearrangement in the periplasmic domain of the flagellar stator B subunit activates peptidoglycan binding and ion influx. Structure 26, $590-598$
73) Kojima, S., Terashima, H., Homma, M. (2020): Regulation of the single polar flagellar biogenesis. Biomolecules 10, 533.

74) Kondo, S., Homma, M., Kojima, S. (2017): Analysis of the GTPase motif of FlhF in the control of the number and location of polar flagella in Vibrio alginolyticus. Biophy. Physicobiol. 14, 173-181.

75) Kondo, S., Imura, Y., Mizuno, A., Homma, M., Kojima, S. (2018): Biochemical analysis of GTPase FlhF which controls the number and position of flagellar formation in marine Vibrio. Sci. Rep. 8, 12115 .

76) Koonin, E.V., Makarova, K.S., Aravind, L. (2001): Horizontal gene transfer in prokaryotes: quantification and classification. Annu. Rev. Microbiol. 55, 709-742.

77) Kubori, T., Shimamoto, N., Yamaguchi, S., Namba, K., Aizawa, S. (1992): Morphological pathway of flagellar assembly in Salmonella typhimurium. J. Mol. Biol. 226, 433-446.

78) Kuhlen, L., Abrusci, P., Johnson, S., Gault, J., Deme, J., Caesar, J., Dietsche, T., Mebrhatu, M.T., Ganief, T., Macek, B., Wagner, S., Robinson, C.V., Lea, S.M. (2018): Structure of the core of the type III secretion system export apparatus. Nat. Struc. Mol. Biol. 25, 583-590.

79) Kuhlen, L., Johnson, S., Zeitler, A., Baurle, S., Deme, J.C., Caesar, J.J.E., Debo, R., Fisher, J., Wagner, S., Lea, S.M. (2020): The substrate specificity switch FlhB assembles onto the export gate to regulate type three secretion. Nat. Commun. 11, 1296.

80) Kusumoto, A., Kamisaka, K., Yakushi, T., Terashima, H., Shinohara, A., Homma, M. (2006): Regulation of polar flagellar number by the $f l h F$ and $f l h G$ genes in Vibrio alginolyticus. J. Biochem. 139, 113-121.

81) Kusumoto, A., Shinohara, A., Terashima, H., Kojima, S., Yakushi, T., Homma, M. (2008): Collaboration of FlhF and FlhG to regulate polar-flagella number and localization in Vibrio alginolyticus. Microbiology 154, 1390-1399.

82) Kutsukake, K., Ikebe, T., Yamamoto, S. (1999): Two novel regulatory genes, fliT and fliZ, in the flagellar regulon of Salmonella. Genes Genet. Syst. 74, 287-292.

83) Kutsukake, K., Iyoda, S., Ohnishi, K., Iino, T. (1994): Genetic and molecular analyses of the interaction between the flagellum-specific sigma and anti-sigma factors in Salmonella typhimurium. EMBO J. 13, 4568-4576.

84) Lee, L.K., Ginsburg, M.A., Crovace, C., Donohoe, M., Stock, D. (2010): Structure of the torque ring of the flagellar motor and the molecular basis for rotational switching. Nature 466 , 996-1000.

85） Lee, S.Y., Cho, H.S., Pelton, J.G., Yan, D., Berry, E.A., Wemmer, D.E. (2001): Crystal structure of activated CheY. Comparison with other activated receiver domains. J. Biol. Chem. 276, 16425-16431.

86) Li, H., Sourjik, V. (2011): Assembly and stability of flagellar motor in Escherichia coli. Mol. Microbiol. 80, 886-899.

87) Liu, X.F., Cao, Y., Zhang, H.L., Chen, Y.J., Hu, C.J. (2015): Complete Genome Sequence of Vibrio alginolyticus ATCC 17749T. Genome Announc. 3, e01500-14.

88) Liu, X.Y., Matsumura, P. (1994): The FlhD;FlhC complex, a transcriptional activator of the Escherichia coli flagellar class II operons. J. Bacteriol. 176, 7345-7351.

89) Lloyd, S.A., Whitby, F.G., Blair, D.F., Hill, C.P. (1999): Structure of the C-terminal domain of FliG, a component of the rotor in the bacterial flagellar motor. Nature 400, 472-475.

90) Lynch, M.J., Levenson, R., Kim, E.A., Sircar, R., Blair, D.F., Dahlquist, F.W., Crane, B.R. (2017): Co-folding of a FliF-FliG split domain forms the basis of the MS: C ring interface within the bacterial flagellar motor. Structure 25, 317-328. 
91) Macnab, R.M. (1992): Genetics and biogenesis of bacterial flagella. Annu. Rev. Genet. 26, 131-158.

92) Macnab, R.M. (1999): The bacterial flagellum: reversible rotary propellor and type III export apparatus. J. Bacteriol. 181, 7149-7153.

93) Macnab, R.M. (2003): How bacteria assemble flagella. Annu. Rev. Microbiol. 57, 77-100.

94) Maki-Yonekura, S., Matsuoka, R., Yamashita, Y., Shimizu, H., Tanaka, M., Iwabuki, F., Yonekura, K. (2018): Hexameric and pentameric complexes of the ExbBD energizer in the Ton system. eLife 7, e35419.

95) Martinez, R.M., Jude, B.A., Kirn, T.J., Skorupski, K., Taylor, R.K. (2010): Role of FlgT in Anchoring the Flagellum of Vibrio cholerae. J. Bacteriol. 192, 2085-2092.

96) Matilla, M.A., Krell, T. (2017): Chemoreceptor-based signal sensing. Curr. Opin. Biotechnol. 45, 8-14.

97) Matsuura, S., Shioi, J., Imae, Y. (1977): Motility in Bacillus subtilis driven by an artificial protonmotive force. FEBS Lett. 82, 187-190.

98) Mauriello, E.M.F., Jones, C., Moine, A., Armitage, J.P. (2018): Cellular targeting and segregation of bacterial chemosensory systems. FEMS Microbiol. Rev. 42, 462-476.

99) Mccarter, L., Hilmen, M., Silverman, M. (1988): Flagellar dynamometer controls swarmer cell differentiation of $V$. parahaemolyticus. Cell 54, 345-351.

100) Mccarter, L.L. (1994): MotX, the channel component of the sodium-type flagellar motor. J. Bacteriol. 176, 5988-5998.

101) Mccarter, L.L. (1994): MotY, a component of the sodium-type flagellar motor. J. Bacteriol. 176, 4219-4225.

102) Mccarter, L.L. (1995): Genetic and molecular characterization of the polar flagellum of Vibrio parahaemolyticus. J. Bacteriol. 177, 1595-1609.

103) Mccarter, L.L. (2001): Polar flagellar motility of the Vibrionaceae. Microbiol. Mol. Biol. Rev. 65, 445-462.

104) Mccarter, L.L. (2004): Dual flagellar systems enable motility under different circumstances. J. Mol. Microbiol. Biotechnol. 7, $18-29$.

105) Mcevoy, M.M., Bren, A., Eisenbach, M., Dahlquist, F.W. (1999): Identification of the binding interfaces on CheY for two of its targets, the phosphatase $\mathrm{Che} Z$ and the flagellar switch protein fliM. J. Mol. Biol. 289, 1423-1433.

106) Minamino, T. (2014): Protein export through the bacterial flagellar type III export pathway. Biochim. Biophys. Acta, 1843, 1642-1648.

107) Minamino, T., Imada, K., Kinoshita, M., Nakamura, S., Morimoto, Y.V., Namba, K. (2011): Structural insight into the rotational switching mechanism of the bacterial flagellar motor. PLoS Biol. 9, e1000616.

108) Minamino, T., Kinoshita, M., Hara, N., Takeuchi, S., Hida, A., Koya, S., Glenwright, H., Imada, K., Aldridge, P.D., Namba, K. (2012): Interaction of a bacterial flagellar chaperone FlgN with FlhA is required for efficient export of its cognate substrates. Mol. Microbiol. 83, 775-788.

109) Minamino, T., Macnab, R.M. (1999): Components of the Salmonella flagellar export apparatus and classification of export substrates. J. Bacteriol. 181, 1388-1394.

110) Minamino, T., Namba, K. (2008): Distinct roles of the FliI ATPase and proton motive force in bacterial flagellar protein export. Nature 451, 485-488.

111) Mirel, D.B., Lustre, V.M., Chamberlin, M.J. (1992): An operon of Bacillus subtilis motility genes transcribed by the sigma D form of RNA polymerase. J. Bacteriol. 174, 4197-4204.

112) Miwatani, T., Shinoda, S., Fujino, T. (1970): Purification of monotrichous flagella of Vibrio parahaemolyticus. Biken J. 13, 149-155.

113) Morimoto, Y.V., Ito, M., Hiraoka, K.D., Che, Y.S., Bai, F., Kami-Ike, N., Namba, K., Minamino, T. (2014): Assembly and stoichiometry of FliF and FlhA in Salmonella flagellar basal body. Mol. Microbiol. 91, 1214-1226.

114) Namba, K., Yamashita, I., Vonderviszt, F. (1989): Structure of the core and central channel of bacterial flagella. Nature 342, 648-654.

115) Nambu, T., Minamino, T., Macnab, R.M., Kutsukake, K. (1999): Peptidoglycan-hydrolyzing activity of the FlgJ protein, essential for flagellar rod formation in Salmonella typhimurium. J. Bacteriol. 181, 1555-1561.

116) Nishihara, Y., Kitao, A. (2015): Gate-controlled proton diffusion and protonation-induced ratchet motion in the stator of the bacterial flagellar motor. Proc. Natl. Acad. Sci. U.S.A. 112, 7737-7742.

117) Nishikino, T., Hijikata, A., Miyanoiri, Y., Onoue, Y., Kojima, S., Shirai, T., Homma, M. (2018) : Rotational direction of flagellar motor from the conformation of FliG middle domain in marine Vibrio. Sci. Rep. 8, 17793.

118) Nishino, Y., Onoue, Y., Kojima, S., Homma, M. (2015): Functional chimeras of flagellar stator proteins between $E$. coli MotB and Vibrio PomB at the periplasmic region in Vibrio or $E$. coli. Microbiologyopen 4, 323-331

119) Nishiyama, S., Suzuki, D., Itoh, Y., Suzuki, K., Tajima, H., Hyakutake, A., Homma, M., Butler-Wu, S.M., Camilli, A. Kawagishi, I. (2012): Mlp24 (McpX) of Vibrio cholerae implicated in pathogenicity functions as a chemoreceptor for multiple amino acids. Infect. Immun. 80, 3170-3178.

120) Nishiyama, S., Takahashi, Y., Yamamoto, K., Suzuki, D., Itoh, Y., Sumita, K., Uchida, Y., Homma, M., Imada, K., Kawagishi, I. (2016): Identification of a Vibrio cholerae chemoreceptor that senses taurine and amino acids as attractants. Sci. Rep. 6, 20866.

121) Noinaj, N., Guillier, M., Barnard, T.J., Buchanan, S.K. (2010): TonB-dependent transporters: regulation, structure, and function. Annu. Rev. Microbiol. 64, 43-60.

122) Ogawa, R., Abe-Yoshizumi, R., Kishi, T., Homma, M., Kojima, S. (2015): Interaction of the C-Terminal tail of FliF with FliG from the $\mathrm{Na}^{+}$-driven flagellar motor of Vibrio alginolyticus. J. Bacteriol. 197, 63-72.

123) Ohnishi, K., Kutsukake, K., Suzuki, H., Ino, T. (1992): A novel transcriptional regulation mechanism in the flagellar regulon of Salmonella-Typhimurium: An anti-sigma factor inhibits the activity of the flagellum-specific sigma factor, $\sigma^{\mathrm{F}}$. Mol. Microbiol. 6, 3149-3157.

124) Ohnishi, K., Ohto, Y., Aizawa, S.I., Macnab, R.M., Iino, T. (1994): $\mathrm{FlgD}$ is a scaffolding protein needed for flagellar hook assembly in Salmonella typhimurium. J. Bacteriol. 176, 2272-2281.

125) Okabe, M., Yakushi, T., Asai, Y., Homma, M. (2001): Cloning and characterization of $m o t X$, a Vibrio alginolyticus sodium-driven flagellar motor gene. J. Biochem. 130, 879-884.

126) Okabe, M., Yakushi, T., Homma, M. (2005): Interactions of MotX with MotY and with the PomA/PomB sodium ion channel complex of the Vibrio alginolyticus polar flagellum. J. Biol. Chem. 280, 25659-25664.

127) Okabe, M., Yakushi, T., Kojima, M., Homma, M. (2002): MotX and MotY, specific components of the sodium-driven flagellar motor, colocalize to the outer membrane in Vibrio alginolyticus. Mol. Microbiol. 46, 125-134.

128) Okada, K., Iida, T., Kita-Tsukamoto, K., Honda, T. (2005): Vibrios commonly possess two chromosomes. J. Bacteriol. 187, 
752-757.

129) Okunishi, I., Kawagishi, I., Homma, M. (1996): Cloning and characterization of $\operatorname{mot} Y$, a gene coding for a component of the sodium-driven flagellar motor in Vibrio alginolyticus. J. Bacteriol. 178, 2409-2415.

130) Ono, H., Takashima, A., Hirata, H., Homma, M., Kojima, S. (2015): The MinD homolog FlhG regulates the synthesis of the single polar flagellum of Vibrio alginolyticus. Mol. Microbiol. 98, 130-141.

131) Onoue, Y., Iwaki, M., Shinobu, A., Nishihara, Y., Iwatsuki, H., Terashima, H., Kitao, A., Kandori, H., Homma, M. (2019): Essential ion binding residues for $\mathrm{Na}^{+}$flow in stator complex of the Vibrio flagellar motor. Sci. Rep. 9, 11216.

132) Ortega, A., Zhulin, I.B., Krell, T. (2017): Sensory repertoire of bacterial chemoreceptors. Microbiol. Mol. Biol. Rev. 81, e0003317.

133) Pal, D., Venkova-Canova, T., Srivastava, P., Chattoraj, D.K. (2005): Multipartite regulation of $\mathrm{rctB}$, the replication initiator gene of Vibrio cholerae chromosome II. J. Bacteriol. 187, 71677175.

134) Pandza, S., Baetens, M., Park, C.H., Au, T., Keyhan, M., Matin, A. (2000): The G-protein FlhF has a role in polar flagellar placement and general stress response induction in Pseudomonas putida. Mol. Microbiol. 36, 414-423.

135) Paul, K., Erhardt, M., Hirano, T., Blair, D.F., Hughes, K.T. (2008): Energy source of flagellar type III secretion. Nature 451, 489-492.

136) Prouty, M.G., Correa, N.E., Klose, K.E. (2001): The novel s54and s28-dependent flagellar gene transcription hierarchy of Vibrio cholerae. Mol. Microbiol. 39, 1595-1609.

137) Ramachandran, R., Ciaccia, P.N., Filsuf, T.A., Jha, J.K., Chattoraj, D.K. (2018): Chromosome 1 licenses chromosome 2 replication in Vibrio cholerae by doubling the $c r t S$ gene dosage. PLoS Genet. 14, e1007426.

138) Ramachandran, R., Jha, J., Chattoraj, D.K. (2014): Chromosome segregation in Vibrio cholerae. J. Mol. Microbiol. Biotechnol. 24, 360-370.

139) Rossmann, F., Brenzinger, S., Knauer, C., Dorrich, A.K., Bubendorfer, S., Ruppert, U., Bange, G., Thormann, K.M. (2015): The role of FlhF and HubP as polar landmark proteins in Shewanella putrefaciens CN-32. Mol. Microbiol. 98, 727-742.

140) Roujeinikova, A. (2008): Crystal structure of the cell wall anchor domain of MotB, a stator component of the bacterial flagellar motor: implications for peptidoglycan recognition. Proc. Natl. Acad. Sci. U.S.A. 105, 10348-10353.

141) Sakazaki, R., Iwanami, S., Fukumi, H. (1963): Studies on the enteropathogenic, facultatively halophilic bacteria, Vibrio parahaemolyticus. Jpn. J. Med. Sci. Biol. 16, 161-188.

142) Sakuma, M., Nishikawa, S., Inaba, S., Nishigaki, T., Kojima, S., Homma, M., Imada, K. (2019): Structure of the periplasmic domain of SflA involved in spatial regulation of the flagellar biogenesis of Vibrio reveals a TPR/SLR-like fold. J. Biochem. 166, 197-204.

143) Santiveri, M., Roa-Eguiara, A., KüHne, C., Wadhwa, N., Berg, H., Erhardt, M., Taylor, N.M.I. (2020) : Structure and function of stator units of the bacterial flagellar motor. Cell 183, 244-257.

144) Sar, N., Mccarter, L., Simon, M., Silverman, M. (1990): Chemotactic control of the two flagellar systems of Vibrio parahaemolyticus. J. Bacteriol, 172, 334-341.

145) Sarkar, M.K., Paul, K., Blair, D. (2010): Chemotaxis signaling protein CheY binds to the rotor protein FliN to control the direction of flagellar rotation in Escherichia coli. Proc. Natl. Acad. Sci. U.S.A. 107, 9370-9375.
146) Sato, K., Homma, M. (2000): Functional reconstitution of the $\mathrm{Na}^{+}$-driven polar flagellar motor component of Vibrio alginolyticus. J. Biol. Chem. 275, 5718-5722.

147) Sato, K., Homma, M. (2000): Multimeric structure of PomA, the $\mathrm{Na}^{+}$-driven polar flagellar motor component of Vibrio alginolyticus. J. Biol. Chem. 275, 20223-20228.

148) Sawabe, T., Kita-Tsukamoto, K., Thompson, F.L. (2007): Inferring the evolutionary history of vibrios by means of multilocus sequence analysis. J. Bacteriol. 189, 7932-7936.

149) Song, W.S., Cho, S.Y., Hong, H.J., Park, S.C., Yoon, S.I. (2017): Self-oligomerizing structure of the flagellar cap protein FliD and its implication in filament assembly. J. Mol. Biol. 429, 847-857.

150) Soutourina, O.A., Bertin, P.N. (2003): Regulation cascade of flagellar expression in Gram-negative bacteria. FEMS Microbiol. Rev. 27, 505-523.

151) Sowa, Y., Rowe, A.D., Leake, M.C., Yakushi, T., Homma, M., Ishijima, A., Berry, R.M. (2005): Direct observation of steps in rotation of the bacterial flagellar motor. Nature 437, 916-919.

152) Stewart, B.J., Mccarter, L.L. (1996): Vibrio parahaemolyticus FlaJ, a homologue of FliS, is required for production of a flagellin. Mol. Microbiol. 20, 137-149.

153) Stewart, B.J., Mccarter, L.L. (2003): Lateral flagellar gene system of Vibrio parahaemolyticus. J. Bacteriol. 185, 4508-4518.

154) Suzuki, T., Iino, T., Horiguchi, T., Yamaguchi, S. (1978): Incomplete flagellar structures in nonflagellate mutants of Salmonella typhimurium. J. Bacteriol. 133, 904-915.

155) Syed, K.A., Beyhan, S., Correa, N., Queen, J., Liu, J., Peng, F., Satchell, K.J., Yildiz, F., Klose, K.E. (2009): The Vibrio cholerae flagellar regulatory hierarchy controls expression of virulence factors. J. Bacteriol. 191, 6555-6570.

156) Syvanen, M. (2012): Evolutionary implications of horizontal gene transfer. Annu. Rev. Genet. 46, 341-358.

157) Takahashi, Y., Nishiyama, S.I., Kawagishi, I., Imada, K. (2020): Structural basis of the binding affinity of chemoreceptors Mlp24p and Mlp37p for various amino acids. Biochem. Biophy. Res. Comm. 523, 233-238.

158) Takahashi, Y., Nishiyama, S.I., Sumita, K., Kawagishi, I., Imada, K. (2019): Calcium ions modulate amino acid sensing of the chemoreceptor Mlp24 of Vibrio cholerae. J. Bacteriol. 201, e00779-18

159) Takekawa, N., Kojima, S., Homma, M. (2014): Contribution of many charged residues at the stator-rotor interface of the $\mathrm{Na}^{+}$-driven flagellar motor to torque generation in Vibrio alginolyticus. J. Bacteriol. 196, 1377-1385.

160) Takekawa, N., Kwon, S., Nishioka, N., Kojima, S., Homma, M. (2016): HubP, a polar landmark protein, regulates flagellar number by assisting in the proper polar localization of FlhG in Vibrio alginolyticus. J. Bacteriol. 198, 3091-3098.

161) Takekawa, N., Nishiyama, M., Kaneseki, T., Kanai, T., Atomi, H., Kojima, S., Homma, M. (2015): Sodium-driven energy conversion for flagellar rotation of the earliest divergent hyperthermophilic bacterium. Sci. Rep. 5, 12711.

162) Takekawa, N., Terauchi, T., Morimoto, Y.V., Minamino, T., Lo, C.J., Kojima, S., Homma, M. (2013): $\mathrm{Na}^{+}$conductivity of the $\mathrm{Na}^{+}$-driven flagellar motor complex composed of unplugged wild-type or mutant PomB with PomA. J. Biochem. 153, 441-451.

163) Terahara, N., Krulwich, T.A., Ito, M. (2008): Mutations alter the sodium versus proton use of a Bacillus clausii flagellar motor and confer dual ion use on Bacillus subtilis motors. Proc. Natl. Acad. Sci. U.S.A. 105, 14359-14364.

164) Terashima, H., Fukuoka, H., Yakushi, T., Kojima, S., Homma, M. (2006): The Vibrio motor proteins, MotX and MotY, are 
associated with the basal body of Na-driven flagella and required for stator formation. Mol. Microbiol. 62, 1170-1180.

165) Terashima, H., Hirano, K., Inoue, Y., Tokano, T., Kawamoto, A., Kato, T., Yamaguchi, E., Namba, K., Uchihashi, T., Kojima, S., Homma, M. (2020): Assembly mechanism of a supramolecular MS-ring complex to initiate bacterial flagellar biogenesis in Vibrio species. J. Bacteriol. 202, e00236-20.

166) Terashima, H., Kawamoto, A., Tatsumi, C., Namba, K., Minamino, T., Imada, K. (2018): In Vitro Reconstitution of Functional Type III Protein Export and Insights into Flagellar Assembly. mBio 9, e00988-18.

167) Terashima, H., Koike, M., Kojima, S., Homma, M. (2010): The flagellar basal body-associated protein FlgT is essential for a novel ring structure in the sodium-driven Vibrio motor. J. Bacteriol. 192, 5609-5615.

168) Terashima, H., Kojima, S., Homma, M. (2008): Flagellar motility in bacteria structure and function of flagellar motor. Int. Rev. Cell Mol. Biol. 270, 39-85.

169) Terashima, H., Li, N., Sakuma, M., Koike, M., Kojima, S., Homma, M., Imada, K. (2013): Insight into the assembly mechanism in the supramolecular rings of the sodium-driven Vibrio flagellar motor from the structure of FlgT. Proc. Natl. Acad. Sci. U.S.A. 110, 6133-6138.

170) Thompson, F.L., Iida, T., Swings, J. (2004): Biodiversity of Vibrios. Microbiol. Mol. Biol. Rev. 68, 403-431.

171) Tomoyasu, T., Ohkishi, T., Ukyo, Y., Tokumitsu, A., Takaya, A., Suzuki, M., Sekiya, K., Matsui, H., Kutsukake, K., Yamamoto, T. (2002): The ClpXP ATP-dependent protease regulates flagellum synthesis in Salmonella enterica serovar typhimurium. J. Bacteriol. 184, 645-653.

172) Tu, Z., Li, H., Zhang, X., Sun, Y., Zhou, Y. (2017): Complete genome sequence and comparative genomics of the golden pompano (Trachinotus ovatus) pathogen, Vibrio harveyi strain QT520. PeerJ 5, e4127.

173) Ueno, T., Oosawa, K., Aizawa, S.I. (1992): M-Ring, S-Ring and proximal rod of the flagellar basal body of Salmonella-Typhimurium are composed of subunits of a single protein, FliF. J. Mol. Biol. 227, 672-677.

174) Upadhyay, A.A., Fleetwood, A.D., Adebali, O., Finn, R.D., Zhulin, I.B. (2016): Cache domains that are homologous to, but different from PAS domains comprise the largest superfamily of extracellular sensors in prokaryotes. PLoS Comput. Biol. 12, e1004862.

175) Waite, A.J., Frankel, N.W., Emonet, T. (2018): Behavioral Variability and Phenotypic Diversity in Bacterial Chemotaxis. Annu. Rev. Biophys. 47, 595-616.

176) Wehbi, H., Portillo, E., Harvey, H., Shimkoff, A.E., Scheurwater, E.M., Howell, P.L., Burrows, L.L. (2011): The peptidoglycanbinding protein FimV promotes assembly of the Pseudomonas aeruginosa type IV pilus secretin. J. Bacteriol. 193, 540-550.

177) Welch, M., Oosawa, K., Aizawa, S.I., Eisenbach, M. (1993): Phosphorylation-dependent binding of a signal molecule to the flagellar switch of bacteria. Proc. Natl. Acad. Sci. U.S.A. 90,
8787-8791.

178) Yabuuchi, E., Miwatani, T., Takeda, Y., Arita, M. (1974): Flagellar morphology of Vibrio parahaemolyticus (Fujino et al) Sakazaki, Iwanami and Fukumi 1963. Jpn. J. Microbiol. 18, 295-305.

179) Yamaichi, Y., Bruckner, R., Ringgaard, S., Moll, A., Cameron, D.E., Briegel, A., Jensen, G.J., Davis, B.M., Waldor, M.K. (2012): A multidomain hub anchors the chromosome segregation and chemotactic machinery to the bacterial pole. Genes Dev. 26, 2348-2360.

180) Yamaichi, Y., Gerding, M.A., Davis, B.M., Waldor, M.K. (2011): Regulatory cross-talk links Vibrio cholerae chromosome II replication and segregation. PLoS Genet. 7, e1002189.

181) Yokoseki, T., Iino, T., Kutsukake, K. (1996): Negative regulation by FliD, FliS, and FliT of the export of the flagellum-specific anti-sigma factor, FlgM, in Salmonella typhimurium. J. Bacteriol. 178, 899-901.

182) Yonekura, K., Maki, S., Morgan, D.G., Derosier, D.J., Vonderviszt, F., Imada, K., Namba, K. (2000): The bacterial flagellar cap as the rotary promoter of flagellin self-assembly. Science 290, 2148-2152.

183) Yorimitsu, T., Homma, M. (2001): $\mathrm{Na}^{+}$-driven flagellar motor of Vibrio. Biochim. Biophys. Acta 1505, 82-93.

184) Yorimitsu, T., Mimaki, A., Yakushi, T., Homma, M. (2003): The conserved charged residues of the C-terminal region of FliG, a rotor component of the $\mathrm{Na}^{+}$-driven flagellar motor. J. Mol. Biol. 334, 567-583.

185) Yorimitsu, T., Sowa, Y., Ishijima, A., Yakushi, T., Homma, M. (2002): The systematic substitutions around the conserved charged residues of the cytoplasmic loop of $\mathrm{Na}^{+}$-driven flagellar motor component PomA. J. Mol. Biol. 320, 403-413.

186) Zhu, S., Nishikino, T., Hu, B., Kojima, S., Homma, M., Liu, J. (2017): Molecular architecture of the sheathed polar flagellum in Vibrio alginolyticus. Proc. Natl. Acad. Sci. U.S.A. 114, 10966 10971.

187) Zhu, S., Nishikino, T., Kojima, S., Homma, M., Liu, J. (2018): The Vibrio H-ring facilitates the outer membrane penetration of the polar sheathed flagellum. J. Bacteriol. 200, e00387-18.

188) Zhu, S., Nishikino, T., Takekawa, N., Terashima, H., Kojima, S., Imada, K., Homma, M., Liu, J. (2020): In situ structure of the Vibrio polar flagellum reveals distinct outer membrane complex and its specific interaction with the stator. J. Bacteriol. 202, e000592-19.

189) Zhu, S., Takao, M., Li, N., Sakuma, M., Nishino, Y., Homma, M., Kojima, S., Imada, K. (2014): Conformational change in the periplamic region of the flagellar stator coupled with the assembly around the rotor. Proc. Natl. Acad. Sci. U.S.A. 111, 13523-13528.

190) Zhuang, X.Y., Guo, S., Li, Z., Zhao, Z., Kojima, S., Homma, M., Wang, P., Lo, C.J., Bai, F. (2020): Live-cell fluorescence imaging reveals dynamic production and loss of bacterial flagella. Mol. Microbiol. 114, 279-291. 


\title{
Flagellar related genes and functions in Vibrio
}

\author{
Tatsuro NISHIKINO ${ }^{1}$, Seiji KOJIMA ${ }^{2}$, and Michio HOMMA ${ }^{2}$ \\ ${ }^{1}$ Institute for Protein Research, Osaka University \\ ${ }^{2}$ Division of Biological Science, Graduate School of Science, Nagoya University
}

Bacteria can move or swim by flagella. On the other hand, the motile ability is not necessary to live at all. In laboratory, the flagella-deficient strains can grow just like the wild-type strains. The flagellum is assembled from more than 20 structural proteins and there are more than 50 genes including the structural genes to regulate or support the flagellar formation. The cost to construct the flagellum is so expensive. The fact that it evolved as a motor organ means even at such the large cost shows that the flagellum is essential for survival in natural condition. In this review, we would like to focus on the flagella-related researches conducted by the authors and the flagellar research on Vibrio spp. 